\title{
Prinsippet om objektiv tolkning
}

\section{- Særlig om tolkning av forhandlede standardavtaler}

Av Inger B. Ørstavik, Ph.D., førsteamanuensis ved Institutt for Privatrett, Universitetet i Oslo

Prinsippet om objektiv tolkning er det sentrale tolkningsprinsipp ved tolkning av kommersielle avtaler. Høyesterett har fremhevet at prinsippet står sarlig sterkt ved tolkning av forhandlede standardkontrakter. Den konkrete tolkningen er i disse tilfellene preget av en «objektiv slagside»: Det finnes som regel få argumenter som kaster lys over hva partene konkret mente, og tolkningen må ofte bero på objektive argumenter. Artikkelen diskuterer om Høyesteretts uttalelser om at den objektive tolkningen har sarlig tyngde, kan bety at det kreves mer for å legge til grunn en felles partsoppfatning som fraviker ordlyden enn ved tolkning av individuelt forhandlede avtaler. Artikkelen konkluderer med at det ikke kan stilles strengere krav til bevisene for den felles partsoppfatning. Når partenes felles mening utledes gjennom tolkning, vil imidlertid tolkningsresultatet trekkes mot den objektive forståelsen av ordlyden. Artikkelen diskuterer videre hvordan «overskuddet» av objektive tolkningsargumenter kan gjøre tolkningen av ordlyden mer generell og abstrahert enn ved tolkning av individuelt forhandlede kontrakter. Dermed blir tolkningsresultatet ofte likt selv om standarden brukes $i$ ulike avtaleforhold. Det at den objektive tolkningen har sarlig tyngde, kan vare et navn på dette resultatet, uten at det oppstilles egne tolkningsregler for forhandlede standardkontrakter.

\section{Objektiv tolkning og særtrekkene ved forhandlede standardkontrakter ${ }^{1}$}

\subsection{Problemstillingen}

At avtaler skal tolkes objektivt, fremheves ofte som «det sentrale tolkningsprinsipp» for kommersielle avtaler, jf. Rt-2002-1155. ${ }^{2}$ Høyesterett har også fremhevet at den objektive tolkningen har særlig gjennomslagskraft ved tolkning av standardkontrakter som er forhandlet frem mellom representanter

\footnotetext{
${ }^{1}$ Takk til professor Kåre Lilleholt som har lest tidligere versjoner av manuset.

2 Jf. også Rt-2003-1132 avsnitt 34, Rt-2005-1447 avsnitt 32 og Rt-2011-1553 avsnitt 47. Jeg bruker «tolkningsprinsipp» om den overordnede metoden for tolkningen. Omtrent slik oppfatter jeg at begrepet er brukt av Høyesterett i Rt-2002-1155.
} 
for bransjeinteresser. ${ }^{3}$ Høyesterett har uttalt seg på lignende måte om entreprisekontrakter, ${ }^{4}$ garantier ${ }^{5}$ og tariffavtaler. ${ }^{6}$ Fellestrekk for disse avtalene, er at de er forhandlet frem og skrevet av andre enn de konkrete partene i avtaleforholdet, og at de brukes i avtaleforhold som kan få betydning for flere enn to parter. Artikkelen tar utgangspunkt i de særlige trekkene ved de forhandlede standardkontraktene, og undersøker hva det betyr at den objektive tolkningen har særlig vekt. Diskusjonen vil ha overføringsverdi til andre avtaletyper der tilsvarende hensyn gjør seg gjeldende i tolkningen. ${ }^{7}$

Forhandlede standardkontrakter brukes hyppig i mange bransjer, og blant de største er Norsk Sjøforsikringsplan, ${ }^{8}$ NS-standardene for entrepriseforhold og Norsk Teknisk Standard og Norsk Fabrikasjonskontrakt (NTK/NF) ${ }^{9}$ som brukes i petroleumssektoren. Mange av de store standardene har voldgiftsklausuler, og det finnes derfor lite tilgjengelig rettspraksis om dem. I kontraktene i NSfamilien, avgjøres mindre tvister som hovedregel ved de alminnelige domstolene, og det finnes derfor noe rettspraksis om disse. ${ }^{10}$ Når jeg tar utgangspunkt i de særlige hensynene ved tolkning av forhandlede standardkontrakter, er det ikke nødvendig å begrense fremstillingen til en bestemt standard eller klart definere begrepet «standardkontrakt». I den grad kontraktene er ulike, får det heller betydning for i hvilken grad hensynene får gjennomslag i tolkningen.

Noen avgrensninger må gjøres. Jeg behandler ikke ensidige standardvilkår, heller ikke forbrukerforhold og tariffavtaler. Jeg viser til ensidige standardvilkår som forsikringsvilkår der det kan illustrere motsetninger eller typeeksempler. Ensidige standardvilkår reiser typisk tolkningsspørsmål som følge av at den ene parten har større forhandlingsstyrke enn den andre, et problem som presumptivt er avhjulpet når kontrakten er fremforhandlet mellom organisasjoner.

All avtaletolkning er konkret, og har som mål å løse et konkret tolkningsspørsmål. De forhandlede standardkontraktene er imidlertid utarbeidet uavhengig av det individuelle avtaleforholdet og med sikte på å brukes i mange, fremtidige avtaleforhold. ${ }^{11}$ Spørsmålet her er hvordan det påvirker den konkrete tolkningen i et individuelt avtaleforhold. Det kan for det første diskuteres om det skal mer til

\footnotetext{
${ }^{3}$ Jf. Rt-2010-1345 avsnitt 59. Se også Geir Woxholth, Avtalerett, 2017 s. 443, Jan Hellner, «Tolkning av standardavtal», JV, 1994 s. 266 på s. 275, Ulf Bernitz, Standardavtalsrätt, 2013, s. 86 (Bernitz 2013).

${ }^{4}$ Jf. Rt-2012-1279.

5 Jf. Rt-2005-1447 og Rt-2011-1553.

${ }^{6}$ Jf. Rt-2004-297.

${ }^{7}$ Diskusjonen er også overførbar til dansk og svensk rett, dog med visse nyanseringer som påpekes underveis.

${ }^{8}$ The Nordic Marine Insurance Plan of 2013, Version 2016 (Sjøforsikringsplanen), forhandlet frem mellom Cefor og de nordiske rederiforbundene.

${ }^{9}$ Norsk Fabrikasjonskontrakt 2015 (NF 15) og Norsk Totalkontrakt 2015 (NTK 15), Norsk Totalkontrakt Modifikasjon 2015 (NTK MOD15), og to ytterligere varianter av NTK MOD 15. Kontraktene er fremforhandlet mellom Norsk Industri og Norsk olje og gass.

${ }^{10}$ Tvister der kravet er under 100G behandles for de ordinære domstolene, jf. NS 8405 art. 43.3 og 43.4, innført med NS 3430 i 1991.

${ }^{11}$ Se Principles of European Contract Law (PECL) Article 2:209 (3), og blant andre Bernitz 2013 s. 16.
} 
å legge til grunn at partene ved avtaleinngåelsen hadde en felles oppfatning om avtalens innhold som avviker fra ordlyden, objektivt tolket, enn ved tolkning av individuelt forhandlede avtaler (pkt. 2). Det er på den ene siden et spørsmål om kravene til bevis for en felles partsoppfatning er høyere enn ved tolkning av individuelt forhandlede avtaler (pkt. 2.2). På den annen side er det et spørsmål om hvordan ordlyden, objektivt tolket, normerer tolkningen når partenes felles oppfatning utledes i ettertid, med utgangspunkt i hvordan partene med rette kunne oppfatte hverandres utspill (pkt. 2.3). For det andre, kan det at den objektive tolkningen har særlig tyngde, bety at tolkningen er mer generell og abstrahert enn tolkningen av individuelle avtaler, slik at tolkningsresultatet blir likt hver gang den samme standardkontrakten brukes til å regulere et avtaleforhold (pkt. 3 og 4).

Formålet med diskusjonen er å sette de konkrete tolkningsuttalelsene fra rettspraksis, og særlig Høyesterettspraksis, inn i en systematisk teoretisk sammenheng. Fordi norsk Høyesterett følger en tradisjon der avgjørelser om avtaletolkning utformes konkret og pragmatisk, innebærer det å se på konsekvenser av ulike argumentasjonsmønstre. Dermed blir det mulig å trekke noen slutninger om tolkningslærens nærmere teoretiske innhold.

\section{2. "Objektiviserende» særtrekk ved forhandlede standardavtaler}

Forhandlede standardkontrakter kjennetegnes ved at de er fremforhandlet av representanter for bransjeinteresser uavhengig av det individuelle avtaleforholdet. Standardkontraktene er laget for å passe for mange kontraktsforhold av samme type. Kontrakten er forhandlet frem som et hele, og de risikoavveiningene som er gjort for ett vilkår, er ledd i en samlet balansering av partenes plikter og rettigheter. Partene i det konkrete avtaleforholdet behøver dermed ikke å forhandle om (alle) kontraktsvilkårene. ${ }^{12}$ Men, om det senere oppstår tolkningsspørsmål ved gjennomføringen av kontrakten, blir vanskelig å argumentere for at en tolkning har grunnlag i partenes vilje, all den tid partene selv verken har skrevet eller forhandlet om det aktuelle vilkåret. ${ }^{13}$ Dermed kan en ha et «underskudd» på kilder til en konkret forståelse av partenes mening.

Den måten de forhandlede standardkontraktene blir til, og brukes på, gjør at det kan finnes kilder til tolkningsargumenter som en ikke har ved tolkning av individuelt forhandlede avtaler. For noen standardkontrakter finnes dokumentasjon fra organisasjonenes forhandlinger, en form for «forarbeider». For avtaler som brukes ofte, som entreprisekontraktene i NS-familien, kan et lignende tolkningsspørsmål ha vært avgjort av domstolene tidligere. Situasjonen kan beskrives som et «overskudd»av objektive tolkningsargumenter, altså argumenter hentet fra kilder som er uavhengige av de konkrete avtalepartene, og som vil trekke mot samme tolkningsresultat hver gang.

\footnotetext{
${ }^{12}$ Se Mads Andenæs, Kontraktsvilkår, 1989 s. 68 flg., Jan Ramberg og Christina Ramberg, Allmän avtalsrätt, 2016, s. 152. Huser 1983 s. 147 kaller dette et «rasjonaliseringshensyn», innholdet er det samme.

${ }^{13}$ Se Thomas Wilhelmsson, Standardavtal och oskäliga avtalsvillkor, 2008, s. 63 flg.
} 


\section{Objektiv tolkning og partsspesifikk tolkning}

\subsection{Problemstillingen}

Tolkningens primære oppgave er å løse konkrete tolkningsspørsmål i et konkret avtaleforhold. Tolkningsprosessen følger tre «hovedregler»: ${ }^{14}$ (1) Dersom det kan konstateres at partene hadde et omforent syn på innholdet i et vilkår på avtaletidspunktet, $m a ̊$ det legges til grunn. ${ }^{15}$ Det er en konsekvens av privatautonomien. (2) Dersom en part kjente eller måtte kjenne til at kontraktsparten hadde en bestemt mening om et vilkårs innhold, kan han måtte tåle at kontraktspartens oppfatning legges til grunn. Ellers er det (3) avgjørende hvordan hver av partene med rette kunne oppfatte avtalevilkåret, ofte formulert som hvordan en forstandig person med samme kjennskap som partene til bakgrunnen for kontrakten, ville oppfatte vilkåret.

Tolkningsspørsmål oppstår når partene på rettsanvendelsestidspunktet ikke er enige om avtaleforpliktelsenes innhold. Det å finne frem til en felles partsoppfatning (1), er derfor også et spørsmål om tolkning. Innenfor et objektivt tolkningsprinsipp, er tolkningens mål å fastlegge hvordan partene med rette kunne oppfatte kontraktsmotpartens utspill. ${ }^{16}$ Spørsmålet om partene hadde en omforent oppfatning om en forpliktelse (1), er da ikke et spørsmål om den subjektive meningen hos hver av partene, men et spørsmål om hvilken berettiget forventning hver av partene kunne ha på grunnlag av kontraktsmotpartens utspill.

Tolkningen under (1) og (2), beror på argumenter utledet fra kilder som er spesifikke for avtaleforholdet, som partenes korrespondanse før avtaleslutningen. Slik tolkning kaller jeg partsspesifikk tolkning, ${ }^{17}$ for å distansere fra den «renere» objektive tolkningen under (3), som i større grad bygger på argumenter fra kilder uten tilknytning til de konkrete partene. ${ }^{18}$ Spørsmålet her er om det at den objektive tolkningen har særlig tyngde, kan bety at det kreves mer for å legge til grunn at partene hadde en omforent oppfatning (1), eller for å anvende den såkalte god tro-regelen (2), dersom

\footnotetext{
${ }^{14}$ Jf. Kåre Lilleholt, Kontraktsrett og obligasjonsrett, 2017, s. 100 (Lilleholt 2017).

${ }^{15}$ HR-2016-1447-A, avsnitt 38, Rt-2010-961 avsnitt 44, implisitt Rt-2014-866, avsnitt 44, Draft Common Frame of Reference (DCFR) II-4:209.

${ }^{16}$ Særlig klart uttrykt i anbudsretten, se Rt-2007-1489, Byggholt, avsnitt 74-75, og Rt-2014-866, Fjord 1, avsnitt 46-47. Tradisjonelle formuleringer som at tolkningen søker å klarlegge hva partene mente, kan fort bli misvisende, se Lilleholt 2017 , s. 102.

${ }^{17}$ Se også Geir Woxholth, Avtalerett, 2017 s. 418. Mads Bryde Andersen, Grundlaggende aftaleret, 2013 s. 313 flg. bruker begrepet «subjektiv tolkning» om det jeg omtaler som «partsspesifikk» tolkning. Høgberg 2006 s. 25-27, bruker begrepet partsorientert tolkning med henvisning til flere arbeider av Bert Lehrberg.

${ }^{18}$ Den nærmeste språklige motsetningen til «objektiv» tolkning, er «subjektiv» tolkning. Det er kun ensidige rettsstiftende erklæringer som testamenter som kan tolkes etter et rent subjektivt tolkningsprinsipp, uten noen vekt på hvilke berettigede forventninger en annen part får ved lesning av dokumentet, se Geir Woxholth, Avtalerett, 2017, s. 405 og Jo Hov og Alf Petter Høgberg, Alminnelig avtalerett, 2009, s. 251.
} 
det vil føre til et tolkningsresultat som fraviker det som følger av en objektiv tolkning med utgangspunkt i ordlyden (3).

Utgangspunktet for diskusjonen er flere avgjørelser fra Høyesterett de senere årene om tolkning av standardkontrakter og andre avtaler der lignende hensyn gjør seg gjeldende, hvor Høyesterett har fremhevet at den objektive tolkningen har en særlig betydning. I Rt-2010-1345, Oslo Vei, premiss 59, uttaler Høyesterett om tolkningen av NS 3430:

«For kontrakter mellom profesjonelle parter må det foreligge sterke grunner for å fravike det tolkingsalternativ som følger av en naturlig forståelse av ordlyden, jf. Rt-2000-806, Rt-2002-1155 og Rt-2003-1132. Dette gjelder i særlig grad for spørsmål som er regulert av standardkontrakter som er blitt til ved forhandlinger mellom interesseorganisasjoner.» (min utheving).

Rt-2011-1553 gjaldt tolkning av en garanti. Høyesterett slår fast at garantier må tolkes objektivt, og uttaler så i avsnitt 48 :

«Dersom det er klart at partene hadde en felles forståelse av teksten i et avtaledokument, kan den vanligvis legges til grunn uten at det er nødvendig å gå nærmere inn på tolkingen av ordlyden. Men det må - scerlig i forretningsforhold mellom profesjonelle parter - kreves nokså klare holdepunkter for at partene har en omforent forståelse som avviker fra ordlyden. (...)» (min utheving). ${ }^{19}$

Spørsmålet er altså om det skal mer til for å legge til grunn et partsspesifikt tolkningsalternativ som fraviker den objektive tolkningen av ordlyden når partene har brukt en forhandlet standardkontrakt enn når det gjelder en individuelt forhandlet avtale. ${ }^{20}$ Teorien har i liten grad problematisert dette. Tolkningsregler ${ }^{21}$ som formuleres for å håndtere forholdet mellom partsspesifikk (eller «subjektiv») og objektiv tolkning, kan gå ut på at individuelt forhandlede vilkår går foran standardiserte vilkår, ${ }^{22}$ eller at reguleringer i dokumenter som partene selv har forfattet, går foran standardiserte reguleringer, dog slik at dokumentenes innhold må tas i betraktning. ${ }^{23}$ Det finnes også generelle uttalelser om at partsspesifikke hensyn kommer i bakgrunnen ved tolkning av forhandlede standardkontrakter. ${ }^{24}$

\footnotetext{
${ }^{19}$ Se også Rt-1994-581, Rt-2002-1155, Rt-2000-806, Rt-2003-1132 avsnitt 35: «relativt klare holdepunkter for at partene har vært enige om en avvikende forståelse», sml. Rt-1981-445 på s. 451, der Høyesterett sier at det er grunn til å «utvise atskillig varsomhet» ved tolkningen av en standardkontrakt.

${ }^{20}$ Kåre Lilleholt, «Tolking av standardvilkår. Skade på bygning valda av leigars bruk. Høgsterettsdom 29. juni 2016 (HR2016-1447-A)», Nytt i Privatretten, 4/2016 s. 19, formulerer dette som et spørsmål om den «subjektive» tolkningens plass i forhold til «objektiv» tolkning.

${ }^{21} \mathrm{Jeg}$ bruker begrepet tolkningsregler om formulerte retningslinjer for avtaletolkning, se pkt. 5 .

${ }^{22}$ Se for eksempel Rt-1997-1807 på s. 1813, Woxholth 2017, s. 418, Kristian Huser, Avtaletolkning, 1983 s. 581 (Huser 1983), PECL art. 5:104 og UNIDROIT Principles Art. 2.1.21.

${ }^{23}$ Se Sondre Dyrland, Det nye gassmarkedet. Om standardkontrakter for kortsiktig gassalg i Europa og USA, 2008, s. 81-83. ${ }^{24}$ Slik Erlend Haaskjold, Kontraktsforpliktelser, 2013 s. 411 og Huser 1983 s. 149.
} 
Formuleringene er imidlertid like generelle som utgangspunktet, nemlig at partsautonomien har forrang, og at partene binder domstolen med sin felles mening.

Satt på spissen, er problemstillingen hvordan det kan være mulig at det at partene har brukt en forhandlet standardkontrakt til å regulere sitt forhold, kan føre til at det skal mer til for å legge til grunn det tolkningsalternativet som ellers automatisk har forrang, nemlig deres felles oppfatning. Diskusjonen er strukturert slik at pkt. 2.2 tar opp spørsmål knyttet til det faktiske grunnlaget for tolkningen, pkt. 2.3 tar opp avveiningen mellom partsspesifikke og objektive tolkningsargumenter, og pkt. 2.4 tar opp god tro-regelen.

\subsection{Det faktiske grunnlaget for en felles partsoppfatning}

\subsubsection{Avtaletolkningens faktiske side}

Avtaletolkningen består av både faktiske og rettslige spørsmål. Faktisk er det spørsmål om hvilke bevis som finnes, og som kan si noe om hvilke oppfatninger partene hadde ved avtaleinngåelsen. Spørsmålet om hvilke slutninger som kan trekkes fra bevismidlene, og hvordan argumentene avveies mot hverandre, er rettslige spørsmål fordi de styres av rettslige normer for bevisvurdering og av normene for avtaletolkning.

Dersom en ser uttalelsene om den objektive tolkningens særlige gjennomslag som relatert til det faktiske grunnlaget for avtalen, kan det formuleres som et spørsmål om det ved tolkning av standardkontrakter gjelder et skjerpet krav til bevisene for at partene på avtaletidspunktet hadde en felles oppfatning om vilkårets innhold som avvek fra det som følger av en objektiv tolkning av ordlyden. Dette er av naturlige årsaker lite behandlet i rettspraksis. Det er først når partene ikke er enige om forståelsen av avtalen at den bringes inn for domstolene. Ofte er det derfor klart at det ikke finnes holdepunkter for at partene hadde en omforent oppfatning om forpliktelsens innhold. ${ }^{25}$ I praksis kommer spørsmålet opp når domstolen må ta stilling til om den ene part med rette kunne oppfatte den annen parts utspill på en måte som avviker fra den objektive forståelsen av standardkontraktens ordlyd. Da vil retten måtte ta stilling til om det er tilstrekkelig faktisk grunnlag for en slik forståelse i kommunikasjonen mellom partene før avtaleslutningen, som e-poster, muntlige forklaringer, møtereferater og lignende. Denne vurderingen har både faktiske og rettslige sider.

Avtaletolkningslæren, slik den utlegges i nyere norsk teori, har imidlertid ikke noe skarpt skille mellom faktiske spørsmål og rettslig tolkning. ${ }^{26}$ Eldre teori hadde i alle fall i utgangspunktet et nokså klart skille mellom bevis og tolkning.

\footnotetext{
${ }^{25}$ Se for eksempel Rt-1991-719, Rt-2010-961 avsnitt 44, Rt-2012-1729, Rt-2014-520 og HR-2016-1447-A avsnitt 38.

${ }^{26}$ Diskusjon hos Huser 1983 s. 81-85 og s. 460-485 og Høgberg 2006 s. 38.
} 
Stang holdt den delen av prosessen som går ut på å klarlegge det faktiske grunnlaget for avtaleslutningen, utenfor det han kalte tolkning: ${ }^{27}$ «Er en muntlig avtale sluttet, må man, hvis ordlyden er omtvistet, føre bevis for hvad som er sagt. Er det en skriftlig erklæring det gjelder, og er der reist tvil om hvorvidt den er forfalsket, må dette spørsmål bringes på det rene. Det er imidlertid ikke et ledd i tolkningen; tekstkritikk er ikke tolkning.» Arnholm fremhevet at spørsmålene glir over i hverandre: «Tolkningen begynner først når faktum er bragt på det rene - selv om man i praksis ikke alltid tar dette som to skarpt adskilte operasjoner. Det samme gjør seg gjeldende ved tolkningsmomenter utenfor selve disposisjonen, f.eks. partenes efterfølgende opptreden; ett er det å fastslå hvordan de faktisk har forholdt seg, et annet å trekke de riktige slutninger av dette.» ${ }^{28}$

Nyere teori, særlig Huser, argumenterer for å inkludere bevisbedømmelsen i tolkningen.$^{29}$ Det blir da ikke nødvendig å skille mellom faktiske og rettslige spørsmål. Etter dette, har Høgberg nokså generelt konkludert med at kontrakten «står i en mellomposisjon mellom jus og faktum, noe som gjør at våre tolkningsregler står i en mellomposisjon mellom bevisregler og rettskildeprinsipper». ${ }^{30}$

Høyesteretts uttalelser om at det krever «sterke grunner» for å fravike det som følger av den objektive forståelsen av en standardkontrakts ordlyd, aktualiserer skillet mellom faktum og jus i avtaletolkningen. Prosessen med å finne frem til og vekte partsspesifikke tolkningsargumenter, bunner i bevisbedømmelse, fordi den starter med å finne ut hva som faktisk ble sagt, gjort og skrevet. Faktiske forhold knyttet til objektive tolkningsargumenter, som hvorvidt forhandlingsprotokoller til en standardkontrakt er offentlig tilgjengelige eller ikke, håndteres etter rettskildelignende prinsipper, og knyttes direkte til vekten av argumentet. Er forarbeidene ikke tilgjengelige, reduserer det vekten av dem i tolkningen. En slik håndtering av faktiske spørsmål er teoretisk sett ikke mulig i den partsspesifikke delen av tolkningen, fordi partene jo binder domstolen med sin beviste felles oppfatning.

Den videre diskusjonen er strukturert ut fra prosessrettens tilnærming til bevis. Reglene om bevis løser ikke spørsmålene, men kan gi en inngang til å diskutere hvilke regler som avgrenser det faktiske grunnlaget for avtaletolkningen.

\subsubsection{Et skjerpet krav til relevans for bevisene for partsspesifikke fakta?}

For det første kan det stilles spørsmål om det stilles strengere krav til relevansen av de bevis som føres for å underbygge et individuelt tolkningsalternativ. Uttalelser som at det er lite rom for partenes subjektive oppfatninger, ${ }^{31}$ kan muligens peke i denne retningen. Utgangspunktet i prosessrettens bevisregler er fri bevisbedømmelse av de bevis partene velger å bringe inn for retten. ${ }^{32}$ Grensen for de

\footnotetext{
${ }^{27}$ Fredrik Stang, Innledning til formueretten, 1935, s. 452-453. Diskutert hos Høgberg 2006 s. 34-39.

${ }^{28}$ Carl Jacob Arnholm, Larebok i avtalerett, 1978 s. 31.

${ }^{29}$ Huser 1983, s. 8-84, jf. s. 295-297.

${ }^{30}$ Høgberg 2006, s. 79-83, sitat fra s. 83.

${ }^{31}$ Erlend Haaskjold, Kontraktsforpliktelser, 2013 s. 411, tilsvarende Lennart Lynge Andersen og Palle Bo Madsen, Aftaler og mellemmand, 2017 s. 409.

${ }^{32}$ Slik om bevis i avtaletolkning, Mads Bryde Andersen, Grundlaggende aftaleret, 2013 s. 311.
} 
bevis som anses relevante og dermed tillates ført for domstolen, trekkes i norsk rett svært vidt. Tvisteloven § 21-8 gir hjemmel for avskjæring av bevis dersom bevisførselen ikke står i et rimelig forhold til den betydning tvisten har. Etter tvisteloven $§$ 21-3 har partene ansvar og frihet med hensyn til å føre bevis, og i saker om tolkning av privatrettslige avtaler, vil retten måtte bygge på de bevisene partene velger å føre. Prinsippet om fri bevisvurdering, jf. tvisteloven § 21-2, står i norsk rett så sterkt at det er lite behov for regler om avskjæring av bevis, fordi domstolen kan velge å se bort fra bevis som ikke er relevante. ${ }^{33}$ Med et prosessuelt utgangspunkt er det derfor vanskelig å tenke seg faste grenser for hvilke bevis som anses relevante.

Heller ikke innenfor tolkningslæren er det noen tradisjon for å begrense det faktiske tolkningsmaterialet. Norsk tolkningslære har ingen klare relevanskriterier, slik at alle omstendigheter som kan kaste lys over hvordan partene i fellesskap mente å regulere sitt mellomværende, i utgangspunktet kan tas i betraktning. ${ }^{34}$ Grensen for hvilke argumenter som er relevant problematiseres sjelden, og det er ikke noen tradisjon for å sette grenser for hvilke bevis som kan føres for å underbygge argumentene.

Til sammenligning har en i engelsk rett valgt en tilnærming der det faktiske tolkningsmaterialet begrenses gjennom bevisreglene. Regler om «parol evidence», går kort og upresist ut på at i saker om tolkning av skriftlige kontrakter er det begrenset hvilke bevis som tillates ført for at partene under forhandlingene hadde andre oppfatninger om kontraktsvilkårenes innhold enn det som er kommet til uttrykk i den skriftlige avtalen. ${ }^{35}$ Tilgangen på partsspesifikke bevis er begrenset, og dermed dras tolkningsresultatet mot en objektiv forståelse av ordlyden. Dette henger sammen med en grunnleggende forskjell i synet på avtaletekstens stilling i avtaletolkningen i engelsk og norsk rett. Svært grovt oppsummert kan dette forklares slik at mens tolkningen etter engelsk rett går ut på å finne avtaleforpliktelsens innhold innenfor avtalens tekst, er tolkningsprosessens uttrykte mål etter norsk rett å finne frem til hva partene har forpliktet seg til, med utgangspunkt i avtalens tekst, men basert på alle tilgjengelige elementer. ${ }^{36}$

Reglene om bevis er én inngang til å styre tolkningsprosessen. Fordi disse reglene er ulike i norsk og engelsk rett, kan et blikk på engelsk rett vise hvordan regler om bevisenes relevans kan påvirke tolkningsresultatet. Antagelig er det ikke mulig å finne norske domstolsavgjørelser som egentlig kan

\footnotetext{
${ }^{33}$ Se nærmere Anne Robberstad, Sivilprosess, 2015 s. 271-272.

${ }^{34}$ Se Lilleholt 2017, s. 102 jf. s. 106.

${ }^{35}$ Se Chitty on Contracts, 13-099 og Jill Poole, Casebook on Contract Law, 2016 s. 209,

DOI:https://doi.org/10.1093/he/9780198732815.001.0001.

${ }^{36}$ Giuditta Cordero-Moss, «Ulike trekk ved norsk og engelsk kontraktsrett og deres betydning for kontraktens virkninger noen komparativrettslige betraktninger», Jussens Venner, 2016, vol. 51, s. 276, DOI: 10.18261/iss.1504-3126-2016-05-02, sier at tolkningen etter norsk rett går ut på å finne frem til forpliktelsenes innhold, der teksten er ett, riktignok viktig, av flere elementer. Lilleholt 2017, s. 105, er mer forbeholden.
} 
belyse dette, fordi domstolen i den konkrete tolkningen bare ser bort fra bevis som domstolen ikke oppfatter som sentrale for tolkningen.

\subsubsection{Et skjerpet krav til bevisenes styrke?}

\subsubsection{Problemet}

Når spørsmålet om partene hadde en omforent forståelse av et vilkår som avviker fra ordlyden, ses i et faktisk perspektiv, må det tas hensyn til at også avtalens ordlyd er et faktum. Selve avtaleteksten er også et bevis, og det er dette de individuelle bevisene holdes opp mot. Da kan spørsmålet om det faktiske grunnlaget for avtalen stilles som et spørsmål om bevisenes styrke. En diskusjon av bevisenes styrke har to sider: for det første, hvem av partene som har risikoen for at et faktum ikke er tilstrekkelig bevist (bevisbyrde), ${ }^{37}$ og for det andre, hvilken grad av sannsynlighet som skal til for at et faktisk forhold legges til grunn som bevist (beviskrav). ${ }^{38}$

\subsubsection{Bevisbyrde}

Det første, bevisbyrde, blir et spørsmål om den part som hevder at partene hadde en omforent oppfatning av vilkårenes innhold, alltid har risikoen for eventuell tvil om det faktiske grunnlaget for den anførte felles partsoppfatningen. Ved tolkning av forhandlede standardkontrakter er det stort sett slik at ordlyden alltid er bevist (jeg ser nå bort fra eventuell tolkningstvil med hensyn til forståelsen av ordlyden.) I Rt-2002-1155, sier Høyesterett «at utgangspunktet om en objektiv fortolkning med basis i kontrakten også kan uttrykkes slik at «den som hevder en forståelse i strid med kontraktens ord, har bevisbyrden for at dette var partenes felles forståelse på avtaletiden». ${ }^{39}$ Saken gjaldt tolkningen av en individuelt forhandlet kommersiell leieavtale, men spørsmålene gjelder tilsvarende ved tolkning av standardavtaler. Uttalelsen er gjentatt i Rt-2012-1729, Mika, avsnitt 58, som gjaldt tolkningen av anbudsgrunnlaget i et entrepriseforhold.

Når kravet til bevis på privatrettens område er sannsynlighetsovervekt, må retten i et valg mellom to alternative fakta (avtalens ordlyd eller partsspesifikt tolkningsalternativ), velge det faktagrunnlaget som er mest sannsynlig. Det er derfor sikker rett at den som hevder et tolkningsalternativ som fraviker ordlyden, også har risikoen for at det er tilstrekkelig dekning for dette alternativet i det faktiske grunnlaget for tolkningen. Det betyr at parten må fremlegge e-poster, føre vitner, eller fremlegge

\footnotetext{
${ }^{37}$ Jf. Markus Jerkø, Bevisvurderingens rettslige rammer, 2017 s. 116, Anne Robberstad, Sivilprosess, 2015 s. 274 . jf. s. 279.

${ }^{38}$ Jf. Anne Robberstad, Sivilprosess, 2015 s. 279. Markus Jerkø, Bevisvurderingens rettslige rammer, 2017 s. 229 flg. forklarer beviskrav som «hvor sterkt må beviset være?», men knytter dette til en sannsynlighetsvurdering, se særlig s. 238 flg., jf. Magne Strandberg, Beviskrav i sivile saker, 2012 særlig oppsummeringen på s. 405. Her er poenget ikke å komme til bunns i prosessrettens diskusjoner om beviskrav og bevisbyrde, men å definere et noenlunde fast punkt for å diskutere om og eventuelt hvordan, en særlig vektlegging av objektiv tolkning kan relateres til avtaletolkningens faktiske side.

${ }^{39}$ Høyesterett siterer fra Erlend Haaskjold, Kontraktsforpliktelser, 2002 på s. 102.
} 
møtereferater som kan dokumentere at de utsagnene han påberoper seg, faktisk fremkom, se for eksempel Rt-2003-1132, Norrønafly, avsnitt 43.

Det er imidlertid helt teoretisk at spørsmålet om partene hadde en felles oppfatning som avvek fra ordlyden, kommer på spissen som et spørsmål om bevisbyrde. I avtaletolkning er det fullt mulig å ha to tolkningsalternativer som bygger på faktiske opplysninger som er like sannsynlige. Det skyldes at bevistemaene er komplementære fremfor gjensidig utelukkende. ${ }^{40}$ Partene kan både ha skrevet under en standardkontrakt med den aktuelle ordlyden, $o g$ ha gitt uttrykk for avvikende oppfatninger om det samme spørsmålet per e-post, i møter eller lignende..$^{41}$ Når alle bevisene er vurdert, kan en altså ha den situasjonen at det faktiske grunnlaget for begge tolkningsalternativer er like sannsynlige. Det er fordi spørsmålet om partene hadde en omforent oppfatning, ikke bare er et spørsmål om bevis, men også tolkning: hvilke berettigede forventninger partene kunne ha med grunnlag i hverandres utspill. For å løse slike motstridstilfeller, må en ta skrittet fra vurderingen av bevis - altså klarlegging av det faktiske grunnlaget for tolkningen - til den rettslige tolkningen. Det vil stort sett være naturlig å betegne valget mellom to like sannsynlige tolkningsalternativer som tolkning. Dette behandles nedenfor i 2.3 .

\subsubsection{Beviskravet}

Den andre siden av spørsmålet om bevisenes styrke, er hvor sannsynlig et faktum må være for å legges til grunn som bevist, altså beviskravet. ${ }^{42}$ Uttalelsene i Rt-2002-1155 åpner muligens for at Høyesterett med uttalelsen om bevisbyrde mener noe mer enn at domstolen må velge det mest sannsynlige faktiske grunnlaget. Noe etter uttalelsen sitert over, sier Høyesterett på s. 1159: «Men subjektive fortolkningsmomenter har også sin selvsagte plass i næringslivets kontrakter. Kan det påvises at kontraktspartene har hatt en felles forståelse som avviker fra kontraktens ordlyd, må dette legges til grunn i rettsforholdet mellom dem. Det generelle utgangspunkt jeg har angitt kan likevel ha betydning for den bevisstyrke som i slike tilfeller må kreves.» (min utheving.)

Spørsmålet er om dette kan forstås slik at det kreves en kvalifisert sannsynlighetsovervekt (altså ikke bare det mest sannsynlige faktum), for å legge det faktiske grunnlaget for det individuelle tolkningsalternativet til grunn. Det vil i så fall bety at det kreves mer for å legge faktagrunnlaget for det individuelle resultatet til grunn, enn ordlyden som faktagrunnlag for den objektive tolkningen.

Jeg har ikke funnet andre uttalelser i Høyesteretts praksis som kan underbygge at det at objektiv tolkning skal ha særlig vekt, har betydning for kravet til bevisenes styrke. I Rt-2003-1132, Norrønafly, gjentar Høyesterett tilnærmet identiske formuleringer som i Rt-2002-1155, men med hensyn til hva

\footnotetext{
${ }^{40}$ Med «bevistema» forstås det faktum som må bevises, se Anne Robberstad, Sivilprosess, 2015 s. 275. Se diskusjon hos Markus Jerkø, Bevisvurderingens rettslige rammer, 2017, s. 130-132. Se pkt. 2.3.1.

${ }^{41}$ Eksempelvis Rt-2014-866, Fjord 1.

42 Jf. Anne Robberstad, Sivilprosess, 2015 s. 279. Ufyllende hos Magne Strandberg, Beviskravet i sivile saker, 2012 s. 17 flg.
} 
som skal til for å fravike en objektiv tolkning av ordlyden på grunnlag av en avvikende, men omforent forståelse mellom partene, sier Høyesterett i avsnitt 35: «Det kreves i slike tilfeller relativt klare holdepunkter for at partene har vært enige om en avvikende forståelse.» (min utheving.) ${ }^{43}$ Verken tidligere, i Rt-2000-806, Oslo Energi, eller senere, som i Rt-2010-1345, Oslo Vei, har Høyesterett uttalt seg nærmere om dette, annet enn å si at det kreves «sterke grunner» eller «klare holdepunkter» ${ }^{44}$ for å fravike en naturlig forståelse av ordlyden, og at for forhandlede standardkontrakter gjelder det «i særlig grad», jf. Rt-2010-1345.

En diskusjon om bevisbyrderegler i avtaletolkning har kommet opp under Kulturdepartementets arbeid med ny åndsverklov. I opphavsretten gjelder en tolkningsregel om at dersom det er uklart hvilke beføyelser som er overdratt fra opphavsmannen, tolkes avtalen i opphavsmannens favør (spesialitetsgrunnsetningen), jf. åndsverkloven § 39. Departementet foreslo først å supplere spesialitetsgrunnsetningen med et tillegg om at erververen av opphavsretten skulle ha bevisbyrden for at avtale var inngått (høringsnotatets forslag § 5-1). I det endelige utkastet har departementet valgt å ikke foreslå noen bevisbyrderegel, se Prop. 104 L (2016-2017) pkt. 6.2.4, fordi det ikke anses nødvendig ved siden av de alminnelige bevisreglene.

Etter mitt syn er det ikke riktig å forstå Høyesteretts uttalelser slik at beviskravet er høyere for partsspesifikke fakta enn for ordlyden som faktagrunnlag for den objektive tolkningen. Dersom en stiller høyere krav til sannsynligheten for partsspesifikke fakta, kan det i siste konsekvens forstyrre utgangspunktet om privatautonomiens forrang. Det kan bli tydelig dersom en sammenligner dette tolkningsproblemet med tolkning av ordlyd i forhold til bakgrunnsretten. Som tolkningsargument virker bakgrunnsretten slik at en velger et tolkningsalternativ som harmonerer med bakgrunnsrettens løsning, eller at jo mer et tolkningsalternativ avviker fra bakgrunnsrettens løsning, jo sterkere argumenter kreves for å legge dette tolkningsalternativet til grunn. ${ }^{45}$ Dette fører til at tolkningsresultatet i større eller mindre grad graviterer mot bakgrunnsrettens løsning. ${ }^{46}$

Begrunnelsen for å la tolkningsresultater gravitere mot bakgrunnsrettens løsning kan imidlertid ikke uten videre overføres til ordlyden i en standardkontrakt. Tolkningsargumentene som hentes fra bakgrunnsretten, er legitimert gjennom samfunnets kontroll med avtalers innhold, ved at bakgrunnsretten tilbyr normalløsninger og dermed både støtter forutberegnelighet og trekker mot bestemte prefererte løsninger. Standardkontraktens ordlyd er legitimert gjennom partsautonomien. Dersom en stiller strengere krav til bevisene for at partene hadde en felles oppfatning, betyr det at tolkningen prefererer det alternativet som er forhandlet mellom organisasjonene, heller enn mellom de

\footnotetext{
${ }^{43}$ Lilleholt 2017. s. 102 oppfatter, slik jeg leser ham, disse uttalelsene som at de peker mot den faktiske siden av avtaletolkningen, men påpeker også at det ikke er klart hva som nærmere ligger i dette.

${ }^{44}$ Jf. Rt-2011-1553 avsnitt 48 og Rt-2012-1267 avsnitt 57, begge om tolkning av garantierklæringer.

${ }^{45}$ Se HR-2016-1447-A avsnitt 44. Lennart Lynge Andersen og Palle Bo Madsen, Aftaler og mellemmand, 2017 s. 359, peker på at den av partene som hevder at det er avtalt en løsning som fraviker bakgrunnsretten, må ha bevisbyrden for det. Det er jeg enig i, men kun så langt det gjelder det faktiske grunnlaget for tolkningen som diskutert over.

${ }^{46}$ Se Kurt Grönfors, Tolkning av fraktavtal, 1989 s. 25 og Anders Ingvarson og Marcus Utterstrøm, «Högsta domstolens intåg i entreprenadrättens slutna rum», SvJT, 2015 s. 258, på s. 271 og s. 277.
} 
konkrete partene. Det krever en annen begrunnelse enn hensynet til samfunnsstyring med avtalers innhold, som ligger under bakgrunnsretten. Derfor vil etter mitt syn det å stille strengere krav til bevisene for den partsspesifikke løsningen enn for standardkontraktens ordlyd, kunne føre til en skjevhet innenfor avtalefrihetens område, slik at privatautonomien begrenses.

Det må imidlertid tas høyde for at kontraktsretten utvikles i sammenheng med utviklingen av de største standardkontraktene. I den grad standardkontraktens løsning anses som en del av bakgrunnsretten, er det ikke samme grunn til å være forbeholden, se pkt. 2.3.2.3 og pkt. 4.2.3.

Noen lovregler er formulert slik at det muligens kreves mer for å fravike dem i avtale. Kjøpslovens § 49 (2) sier at kjøper kan kreve å undersøke tingen før betalingen, men «[k]jøperen kan ikke som følge av en slik undersøkelse utsette betalingen med mer enn 30 dager, med mindre selgeren uttrykkelig har godkjent dette.» ${ }^{47}$ Håndverkertjenesteloven $§ 32(2)$ sier at den endelige prisen for tjenesten ikke kan overstige et gitt prisoverslag med mer enn 15\%, med mindre «en annen prisgrense uttrykkelig er avtalt». I forarbeidene er det bare påpekt at en avtale om en annen prisgrense «bør gå klart fram». ${ }^{48}$ Se også forsikringsavtaleloven $\S 3-2$ annet ledd og forsinkelsesrenteloven $\S 2 b$ annet ledd. Etter mitt syn, er det mest naturlig å se slike krav som et krav til avtalen etter tolkning. Det vil indirekte innebære et krav til bevisene også, fordi det både må være klart at det er gitt et utsagn og det må være klart at utsagnet har et innhold som fraviker lovens løsning.

Etter mitt syn, må fastleggelsen av det faktiske grunnlaget for tolkningen, skje etter vanlige bevisregler. Det er ikke holdepunkter for noen snevrere avgrensning av det faktiske tolkningsmaterialet, jf. pkt. 2.2.2. Jeg mener man heller ikke kan legge til grunn et skjerpet beviskrav for fakta til støtte for partsspesifikke tolkningsargumenter, men må forholde seg til det alminnelige kravet om sannsynlighetsovervekt, jf. pkt. 2.2.3. Når Høyesterett sier at det kreves «klare holdepunkter» eller «sterke grunner» for å legge til grunn et tolkningsalternativ som fraviker ordlyden (objektivt tolket), diskuterer jeg i det videre om og hvordan det kan rette seg mot tolkningens normative side, altså den delen av tolkningsprosessen som er jus.

\subsection{Avveiningen mellom partsspesifikke tolkningsargumenter og det objektive tolkningsalternativet - tolkningens normative side}

\subsubsection{Bevisretten gir ufullstendige svar - bevistemaproblematikk}

Hvorvidt partene hadde en omforent oppfatning som avviker fra ordlyden, er under det objektive tolkningsprinsipp, et spørsmål om hvordan den ene parten med rette kunne forstå utspill fra den annen part (se pkt. 2.1). Det er en rettslig vurdering, basert på det faktiske grunnlaget som partene fører bevis for. Fordi det ligger en rettslig vurdering i dette, blir det lett misvisende dersom bevistemaet formuleres som et spørsmål om det anførte tolkningsalternativet var partenes felles oppfatning ved

\footnotetext{
${ }^{47}$ Bestemmelsen gjennomfører direktiv 2011/7/EU av 16. februar 2011 om kamp mot forsinket betaling i handelsforhold, se Prop. 150 L (2011-2012) pkt. 4.5 .

${ }^{48}$ Ot.prp. nr. 29(1988-1989) s. 96.
} 
avtaleinngåelsen. ${ }^{49}$ Tolkning går ut på å finne frem til en individuell norm, ikke å anvende en generell norm. Etter mitt syn, bør en derfor være svært forsiktig med å sette likhetstegn mellom tolkningsresultatet og bevistemaet, fordi tolkningsresultatet beror på rettsanvendelse (utledning og avveining av tolkningsargumenter) i tillegg til bevisbedømmelse (hva ble sagt, gjort og skrevet). ${ }^{50}$ Resultatet av bevisbedфmmelsen kan være to fakta som begge er mer enn $50 \%$ sannsynlige: partene har både skrevet under standarden og det er sendt en e-post med innhold som avviker fra standarden. Resultatet av rettsanvendelsen, utledningen og avveiningen av tolkningsargumenter, kan imidlertid bare ha ett svar som altså er avtalens norm.

\subsubsection{Avveiningen mellom tolkningsargumentene - typetilfeller}

\subsubsection{Konkret vurdering}

Når det faktiske grunnlaget for tolkningen er klarlagt gjennom bevisvurderingen, blir spørsmålet hvordan partene med rette kunne oppfatte hverandres utspill. Ordlyden er det argument det er naturlig å ta utgangspunkt i. I motsetning til ved individuelt forhandlede avtaler er det imidlertid ikke slik at avtaleteksten er et fors $\varnothing \mathrm{k}$ på å skrive ned den felles oppfatningen partene har kommet frem til. Standardavtalens tekst står på egne ben. Samtidig er argumentene for den partsspesifikke tolkningen ofte fragmentariske, og gir ikke alltid uttrykk for noen fullstendig eller entydig forståelse. Her er spørsmålet hvordan et krav om «sterke grunner» for å fravike avtalens ordlyd kan relateres til den normative tolkningen.

\subsubsection{Avtalte regler om tolkning og motstrid}

Spørsmålet er først om det forhold at avtalens ordlyd er «frikoblet» fra partenes forhandlinger, gjør at en stiller særlige krav til argumentene for det alternativet som anføres som partenes felles oppfatning.

En typisk situasjon er der partene har gjort individuelle reguleringer i ett avtaledokument, og det viser seg at reguleringen går på tvers av en regulering i standardkontraktens bestemmelser. Mange store standardkontrakter bruker dokumenthierarkier for å løse tolkningsspørsmål som følge av motstrid mellom ulike avtaledokumenter. ${ }^{51}$ Slike avtalereguleringer er imidlertid en del av standardavtalen som i utgangspunktet må stå tilbake for individuelle reguleringer på grunn av privatautonomien. Derfor kan verken dokumenthierarkiet, tolkningsbestemmelser i kontrakten eller en tolkningsregel om at en

\footnotetext{
${ }^{49}$ Se diskusjonen hos Magne Strandbakken, Beviskravet i sivile saker, 2012 s. 411-414. Se også Jens Edvin A. Skoghøy, Tvistelфsning, 2017 s. 942-944.

${ }^{50}$ Sml. Markus Jerkø, Bevisvurderingens rettslige rammer, 2017 s. 131-132. Slik jeg oppfatter Jerkø, oppstiller han bevistemaet som de anførte tolkningsalternativene, og dersom ett tolkningsalternativ er mer enn 50\% sannsynlig, løser det tolkningsspørsmålet. Tolkning kommer inn dersom ingen av tolkningsalternativene er mer enn 50\% sannsynlige. Etter mitt syn blir dette ikke helt fullstendig fordi svaret på det faktiske spørsmålet kan være både-og, mens det rettslige spørsmålet utledning av normen som er avtalen, bare kan ha ett svar, altså enten-eller. Geir Woxholth, Avtalerett, 2017 s. 407, synes også å oppfatte spørsmålet om partenes felles oppfatning som et faktisk spørsmål.

${ }^{51}$ Se for eksempel NF/NTK 15 pkt. 2.3, og NS 8406 pkt. 4, jf. NS 8405 pkt. 3.
} 
individuell regulering har forrang foran en generell regulering, fullt ut løse spørsmålene som oppstår i grenselandet mellom partsspesifikk og objektiv tolkning. ${ }^{52}$ For eksempel der den individuelle løsningen fremgår av et «trinnlavere» dokument, eller der en løsning i et «trinnhøyere» dokument er uklar når den holdes opp mot ordlydens løsning. Spørsmålet er om, og eventuelt hvordan, slike reguleringer i avtalen kan føre til at terskelen heves for å legge til grunn at partene har fraveket standardens ordlyd.

Muligens kan en se hen til hvordan domstolene forholder seg til muntlige avtaler i strid med det som i internasjonale kontrakter kalles «no oral amendment» klausuler. Det er klausuler som krever en bestemt form, normalt skriftlighet, for endringer av en skriftlig avtale. Slike klausuler er gyldige; det ligger innenfor partenes kompetanse å binde seg slik. Men det er også innenfor partenes kompetanse å inngå nye avtaler, også muntlige, fordi privatautonomien har forrang. En «no oral amendment» klausul kan derfor antagelig ikke utgjøre mer enn en presumsjon for at endringer av avtalen skjer skriftlig. Dersom partene senere likevel inngår en muntlig avtale, vil nok domstolene anse seg bundet av den, dersom det kan legges til grunn at partenes felles mening ikke bare var en innholdsmessig endring av kontrakten, men også å endre bestemmelsen om formkrav. ${ }^{53}$ Man introduserer dermed et nytt bevistema, fordi det å fravike den skriftlige avtalen ikke bare er et spørsmål om hvilken materielle løsning partene mente skulle gjelde, men også et spørsmål om hvordan partene formelt kommuniserer med hverandre.

I norsk rett er det uvant formalistisk å konkretisere to separate bevistemaer i en slik vurdering. De konkrete bevisene vil neppe legge opp til det heller. Poenget her er en diskusjon av hvordan og hvorfor det kan være legitimt å stille krav til partsspesifikke tolkningsargumenter. Selv om den individuelle løsningen har forrang på grunn av partsautonomien, må en i tolkningen likevel «veie opp for» både det at ordlyden ikke er resultatet av de konkrete forhandlingene, og det at ordlyden (objektivt tolket) nok har særlig vekt ved tolkning av forhandlede standardkontrakter (se pkt. 2.3.2.3).

Rt-1997-1086 kan gi et eksempel. Spørsmålet var om partene i en byggekontrakt som viste til NS3401, hadde fraveket standardens bestemmelser om sluttoppgjør. Etter NS-3401 gikk individuelle reguleringer i byggekontrakten foran bestemmelsene i standarden. Høyesterett sier på s. 1095: «Ved en eventuell motstrid mellom selve byggekontrakten (avtaledokumentet) og NS-3401, går bestemmelsene i avtaledokumentet foran, jf. kontraktens punkt 2.2 og NS-3401 punkt 3.1. Når det på denne måte er henvist til standarden i den byggekontrakt som er forhandlet og inngått mellom partene, må det etter min mening ha et klart holdepunkt i selve byggekontrakten om standardens bestemmelser skal fravikes. Ut fra forhistorien til og utformingen av byggekontraktens punkt 7 om betaling og

\footnotetext{
${ }^{52}$ Annerledes, slik jeg forstår ham, Lasse Simonsen «Motstridende utsagn i kontraktsdokumenter», i Selskap, kontrakt, konkurs og rettskilder, Festskrift til Mads Henry Andenæs, 2010 s. 266.

${ }^{53}$ Se PECL art. 2:106 (1), og Ole Lando og Hugh Beale (red.), Principles of European Contract Law Parts I and II, s. 155.
} 
betalingsfrist er jeg under noen tvil kommet til at bestemmelsen ikke kan forstås slik at den tar sikte på å fravike NS-3401 punkt 24 om sluttoppgjør. Det foreligger da ingen motstrid mellom standarden og avtaledokumentet, og standardens bestemmelser om sluttoppgjør må så langt legges til grunn.»

Poenget her er å få frem at Høyesteretts uttalelser om at det må foreligge «sterke grunner» eller «klare holdepunkter» for å legge til grunn at partene har fraveket standardens ordlyd, kan ses som krav til de partsspesifikke tolkningsargumentene. Dersom det individuelle tolkningsalternativet angir en klar løsning, er det lettere å legge denne til grunn foran en ellers klar ordlyd. ${ }^{54}$ Dersom løsningen ut fra de partsspesifikke argumentene er uklar eller ufullstendig, kan det at det er klart at partene har villet «avtale seg ut av standarden» være et argument for å legge den individuelle løsningen til grunn likevel. Uansett, vil en slik tilnærming til de partsspesifikke tolkningsargumentene ha som resultat at tolkningen trekkes mot ordlydens løsning.

En individuell løsning må ikke være fullstendig for å kunne legges til grunn foran ordlyden. Dersom løsningen kan utfylles med bakgrunnsretten, kan det være klart nok hva partene har ment. Se Rt-2014-866, Fjord 1, om tolkningen av en tjenestekontrakt om drift av en fergestrekning, der Høyesterett kom frem til et tolkningsresultat som viste til læren om bristende forutsetninger. Se også NJA 2012 s. 597, Fortum.

\subsubsection{Ordlyden støttes av andre objektive tolkningsargumenter}

Det er gode argumenter for å tillegge ordlyden stor vekt ved tolkning av forhandlede standardkontrakter. Blant annet har forhandlerne en særlig profesjonalitet, eventuell ubalanse i forhandlingssituasjonen er utlignet når forhandlingene skjer mellom organisasjoner, og kontrakten antas ofte å være balansert og rimelig fullstendig. ${ }^{55}$ Spørsmålet er når argumentene for å legge vekt på ordlyden eventuelt kan begrunne at det skal mer til for å legge til grunn en partsspesifikk løsning.

Tolkningsargumenter knyttet til at den part som ved avtaleinngåelsen mente at et vilkår skulle ha et bestemt innhold, også må ha risikoen for at kontraktens ordlyd reflekterer det innholdet, har hatt stort gjennomslag i norsk rettspraksis, se for eksempel Rt-2000-806, Oslo Energi. Dette er en type argumentasjon som gjerne knyttes til uklarhetsregelen, se pkt. 5.2. Men, det er utslag av mer allmenne hensyn som taler for at ordlyden får større vekt enn andre tolkningsargumenter. På grunn av privatautonomiens forrang, står en ikke helt fritt til å veie alle tolkningsargumentene mot hverandre. Poenget her er å vise hvordan vi i norsk rett tenker om ordlydens betydning i forhold til en felles partsoppfatning når denne utledes i ettertid, og å vise særlige argumenter for ordlydens betydning når partene har brukt en forhandlet standardkontrakt.

I all tolkning av skriftlige avtaler, må en anerkjenne at ordlyden er med på å forme hvilke berettigede forventninger partene kan ha på grunnlag av hverandres utspill. ${ }^{56}$ Ordlyden er jo det sentrale argument for forståelsen av vilkårenes innhold, og den objektive tolkningen av ordlyden er derfor normerende for partenes berettigede forventninger. Ved tolkning av forhandlede standardkontrakter, er ordlyden

\footnotetext{
${ }^{54}$ Sml. Rt-2003-1132. Se Rt-1997-1086 på s. 1095 og Rt-1994-581 på s. 587. Se Kurt Grönfors, Tolkning av fraktavtal, 1989 s. 25.

${ }^{55}$ Jf. Rt-1994-581, Scanvest, om tolkningen av en aksjonæravtale.

${ }^{56}$ Se Høgberg 2006 s. 128.
} 
også nøytral i forhold til partene, fordi det ikke er noen av partene som har skrevet teksten. Allerede dette fører til at tolkningsresultatet trekkes i retning av ordlydens alternativ.

I Rt-1994-581, Scanvest, peker Høyesterett på at holdepunktene for partenes felles mening kan være fragmentariske, og selv om partsautonomien har forrang, vil tolkningstvil ofte løses til fordel for ordlydens løsning: «Avtalen er en forretningsmessig avtale utformet av personer med stor profesjonell kompetanse i slike forhold. Det ville etter mitt syn åpne for tvil og uklarhet om man ved tolkingen av slike avtaler skulle fravike ordlyden ut fra mer eller mindre klare antagelser om formålet.» (s. 587.)

Når det gjelder forhandlede standardkontrakter, kan i tillegg standardens løsning være blitt en del av bakgrunnsretten, se pkt. 4.2.3. I så fall trekkes tolkningsresultatet mot kontraktens løsning på samme måte som tolkningsresultatet kan trekkes mot bakgrunnsrettens løsning, jf. pkt. 2.2.3. Dette kan illustreres ved avgjørelser om vedtagelse av standardkontrakter, idet Høyesterett synes å senke terskelen for kravet til vedtagelse dersom standarden er blitt en del av bakgrunnsretten. Rt-2013-129, Normar Fish, gjaldt spørsmålet om speditørens utvidede tilbakeholdsrett. I speditørens faktura var det vist til NSAB $2000,{ }^{57}$ og det var tilstrekkelig for å anse vilkårene som vedtatt siden den utvidede tilbakeholdsretten i NSAB $\S 14$ uansett var blitt en del av bakgrunnsretten (avsnitt 48). ${ }^{58}$ Dette gjelder særlig de store standardkontraktene som har vært i bruk over lang tid og i stort sett samme form, som NSAB og NS 3401 (nå avløst av NS 8405). En tendens til spesialisering innenfor kontraktsfamiliene kan forstyrre en slik trend. ${ }^{59}$

Også det at standarden brukes i stor utstrekning i en bransje, kan gjøre at dens løsninger blir retningsgivende for hva bransjen anser som gode og rimelige løsninger. Dermed blir ordlyden også en målestokk for tolkningsresultatet, og tolkningsresultatet trekkes mot standardens løsning.

Dersom standardens vilkår er blitt en del av bakgrunnsretten eller er uttrykk for en generelt god eller rimelig løsning, får ordlyden et utvidet legitimasjonsgrunnlag i tolkningen ${ }^{60} \mathrm{I}$ så fall oppstår det ingen «konflikt» mellom standardkontraktens ordlyd og den individuelle løsningen på grunn av privatautonomien.

\subsubsection{Konklusjon}

Når Høyesterett har krevet at det foreligger «sterke grunner» eller «klare holdepunkter» for å legge til grunn et tolkningsresultat som fraviker ordlyden, peker det på resultatet: tolkningsresultatet trekkes mot ordlydens løsning. Dette kan knyttes til særlig to forhold: for det første er tolkningssituasjonen ofte slik at argumentene for at partene har fraveket ordlyden er fragmentariske og ufullstendige.

\footnotetext{
${ }^{57}$ Norsk Speditørforbunds Alminnelige Bestemmelser, fremforhandlet mellom Nordisk Speditørforbund og flere organisasjoner med medlemsbedrifter i Norden. Se også Rt-1973-967.

${ }^{58}$ Se også mindretallet i Rt-2010-1345, Oslo Vei, avsnitt 75 (NS3401).

${ }^{59}$ Dette illustrerer diskusjonen om «civilrättens splittring», slik den har vært ført i svensk teori med utgangspunkt i Bertil Bengtssons artikkel «Om civilrättens splittring», Festskrift til Kurt Grönfors, 1991 s. 29 flg.

${ }^{60}$ Se nedenfor pkt. 4.2.3 og Nils Nygaard, Rettsgrunnlag og standpunkt, 2004 s. 337.
} 
Dermed kan det være berettiget å stille noe strengere krav til det tolkningsalternativet som fraviker avtalens ordlyd. Ordlyden blir også uttrykk for en normalforventing, og normerer vurderingen av partenes berettigede forventninger på grunnlag av kontraktsmaterialet. For det andre, kan standarden være blitt en del av bakgrunnsretten eller være uttrykk for gjengse oppfatninger i bransjen om hva som er en god løsning. I så fall har ordlyden et utvidet legitimasjonsgrunnlag, og kan tillegges mer vekt selv om en individuell løsning på grunn av partsautonomien i utgangspunktet har forrang.

\subsection{God tro-standarden}

Tolkningens andre «hovedregel», jf. pkt. 2.1, går ut på at dersom en part kjenner til eller måtte kjenne til at den andre parten la et annet meningsinnhold i et avtalevilkår enn han selv og han unnlater å reagere om han ikke er enig, kan han måtte akseptere at den annen parts mening legges til grunn ved tolkningen av avtalen. Dette er den såkalte god tro-standarden. Spørsmålet er hvordan god trostandarden fungerer når partene har brukt en forhandlet standardkontrakt.

God tro-standarden bidrar til å sanksjonere utgangspunktet om at et utsagn forstås slik en normalt aktsom person ville oppfatte det. Forventningen til partenes opptreden fastsettes konkret. ${ }^{61}$ Aktsomhetsnormen er de objektive, men konkrete forventningene som stilles til parten. ${ }^{62}$ Regelens forankring i hensynet til lojalitet tilsier at dens sentrale nedslagsfelt er de grovere tilfellene. Regelen har også en viss forankring i reglene i avtaleloven $§ 32 \mathrm{og} \S 33 .{ }^{63}$ I utgangspunktet skal det nok en del til før en parts taushet er så graverende at han blir bundet til den annen parts forståelse.

Formuleringer som i Rt-2002-1155 på s. 1162, hos Johan Giertsen, Avtaler, 2014, s. 118-119, Huser 1983, s. 417-418 og Høgberg 2006 s. 265 jf. s. 275, antyder at god tro-standarden kan anvendes ved alminnelig uaktsomhet, mens Lilleholts formuleringer, 2017 s. 101, tyder på at det skal mer til. Det synes kun å være Norge av de nordiske landene som åpner for å anvende god tro-regelen ved simpel uaktsomhet, se Ole Lando m.fl., Restatement of nordic contract law, 2016, s. 169-170. I svensk rett anvendes god tro-regelen kun overfor den uaktsomme kontraktspart der det er stor ulikevekt i forhandlingsstyrke, se Jan Ramberg og Christina Ramberg, Allmän avtalsrätt, 2016, s. 176 med henvisninger. I europeisk sammenheng er terskelen grov uaktsomhet, se CISG art. 8(1), UNIDROIT Principles art. 4.2 (1) og PECL art. 5:101(2). Fordi god trostandarden beror på en konkret vurdering av om det er grunn til å sanksjonere partens opptreden, kommer terskelen for å anvende en slik tolkningsregel sjelden på spissen.

For at det skal være grunn til å sanksjonere unnlatelsen av å avklare meningsforskjell gjennom god tro-standarden, må parten ha fått en konkret oppfordring til å reagere. Når partene bruker en forhandlet

\footnotetext{
${ }^{61}$ Jf. Lilleholt 2017 s. 101. LA-2006-126227 gjaldt valg av entrepriseform. Der entreprenøren visste at byggherren $\varnothing$ nsket en totalentreprise, kunne han ikke høres med at oppdraget var en utførelsesentreprise selv om byggherren hadde brukt språk i den retningen i korrespondanse før kontraktsinngåelsen. Omtalt hos Alf Johan Knag, Hvordan skrive kontrakt? - en sann historie om фnsketenkning, ukyndighet og annen konfliktskapende virksomhet, i Jan Einar Barbo og Lasse Simonsen (red.) På rett grunn, Festskrift til Norsk Forening for Bygge- og Entrepriserett, 2010 s. 85 på s. 99.

${ }^{62}$ Se Margrethe Buskerud Christoffersen, «Lojalitetspliktens utvikling i nyere norsk rettspraksis», i Erling Hjelmeng red., Ugyldighet i privatretten - minnebok til Viggo Hagstrøm, 2016 s. 153 på s. 176.

${ }^{63}$ Jf. Viggo Hagstrøm og Herman Bruserud, Entrepriserett, 2014, s. 163 og Høgberg 2006, s. 269-274.
} 
standardkontrakt, skjer det ofte lite kommunikasjon om vilkårene som kunne avslørt uenighet. Standardavtalens tekst er heller ikke, som en individuelt forhandlet tekst, partenes formulering av resultatet av forhandlingene. Standardteksten alene er derfor ikke egnet til å kommunisere hvilken subjektive oppfatning en part har om vilkårenes innhold, og introduksjonen av vilkårene alene gir derfor normalt ikke noen konkret oppfordring til å reagere mot en meningsforskjell for den annen part.

Det blir derfor først og fremst der det foreligger konkrete holdepunkter for at kontraktsmotparten har forstått vilkårene på en måte som avviker fra en objektiv forståelse, og kontraktsmotparten har unnlatt å reagere, at det kan være aktuelt å anvende god tro-standarden. I denne situasjonen glir spørsmålet om avtalebinding og avtaletolkning over i hverandre, jf. også avtalelovens regler om for sen og avvikende aksept i 4(2) og § 6(2). ${ }^{64}$ Rt-2011-65 illustrerer dette. Spørsmålet var om prosjektering av endringsarbeider kunne faktureres etter medgått tid under NS 8401. Byggherren hadde fått to varsler om at det ville bli krevet $\varnothing \mathrm{kt}$ honorar, og om at det ville bli fakturert etter medgått tid inntil det forelå enighet om honoraret. Høyesterett mente at når byggherren likevel hadde satt $\mathrm{i}$ gang arbeidene og heller ikke hadde stanset arbeidene eller innledet dialog da det ble klart at partene var uenige, måtte entreprenøren kunne fakturere i henhold til sin oppfatning - for medgått tid (avsnitt 45 og 46). Dette spørsmålet kunne kanskje like gjerne vært løst som et spørsmål om avtalebinding. ${ }^{65}$

Som tolkningsregel får god tro-regelen begrenset betydning i anbudsretten fordi det ikke foregår noen kommunikasjon mellom partene om anbudsgrunnlag og tilbud. Høyesterett har vært avvisende til å pålegge tilbyder noen aktsomhetsplikt med hensyn til feil i innkomne anbud, se Rt-2007-1489, avsnitt 73-75, Rt-2003-1531, avsnitt 43, kritisert av Kåre Lilleholt, «Anbodskonkurranse og mistak», i Boel Flodgren m.fl., Avtalslagen 90 år. Aktuell nordisk rettspraksis., 2005. Se også Kai Krüger, «Tolkning av kontrakter som er tildelt ved anbudskonkurranse», i Jan Einar Barbo og Lasse Simonsen (red.), På rett grunn, Festskrift til Norsk Forening for Bygge- og Entrepriserett, 2010 s. 111 på s. 114-115 og Lasse Simonsen, «Tolkning av anbudsgrunnlag Rt-2007-1489», i Lars Ole Hansen m.fl., Festskrift til Det Danske Selskab for Byggeret, 2009 s. 277. I Rt2012-1729 avsnitt 65, presiserer Høyesterett at det ikke har betydning hvordan tilbyder søker å avklare en uklarhet i anbudsinnbydelsen. Uttalelsen om aktsomhetsplikten ble stående.

\section{Objektiv tolkning av ordlyden skjer innenfor en konkret faktisk ramme} Når avtalen tolkes objektivt, er det avgjørende hvordan en forstandig person med samme kjennskap som partene til bakgrunnen for kontrakten ville oppfatte vilkåret, jf. pkt. 2.1. ${ }^{66}$ Utgangspunktet er den

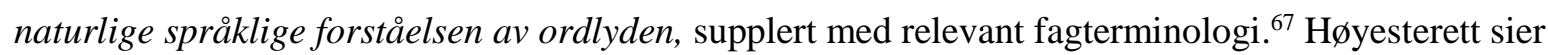

\footnotetext{
${ }^{64}$ Se også Rt-2001-1288, Gate Gourmet, på s. 1298.

${ }^{65}$ Se også LE-2004-9945, som gjaldt spørsmålet om et byggelederoppdrag under NS8401 var inngått til fastpris eller til fastpris med tillegg av timehonorar.

${ }^{66}$ Se Rt-1997-1489 avsnitt 74, jf. Rt-2014-866 avsnitt 46-47, Høgberg 2006, s. 156, Lilleholt 2017, s. 102, Ramberg og Ramberg 2016, s. 42, PECL Art. 5:101 (1) jf. (3), UNIDROIT Principles 2010 Art. 4.1, DCFR II-4:102.

${ }^{67}$ Se bl.a. Lilleholt 2017 s. 107, Bernitz 2013, s. 87, Mads Bryde Andersen, Grundlaggende aftaleret, 2013 s. 325.

Tolkningen er ikke begrenset til en ren ordlydstolkning, se pkt. 4.
} 
også at det er lite rom for en parts individuelle og subjektive oppfatninger. ${ }^{68}$ Den objektive tolkningen skal bidra til å fremme forutsigbarhet: De forventningene som gir grunnlag for rettslig bindende avtaleforpliktelser, holdes innenfor et normalintervall.

Formålet med tolkningen er alltid å løse et konkret tolkningsspørsmål i et konkret avtaleforhold, altså med henblikk på en bestemt faktisk situasjon. Formuleringene i teorien peker nokså generelt på det, når det sies at en tolker ordlyden slik en tredjeperson «under samme omstendigheter» ${ }^{69}$ eller med «samme kunnskap» ville oppfatte den. ${ }^{70}$ Jo mer konkret og individualisert kunnskap en forutsetter at den tenkte tredjeperson har, jo mer individuell og konkret blir også den objektive tolkningen. Det kan få betydning for tolkningsresultatet om den forstandige tredjepersonen ved tolkningen av NF 2015 defineres som en leverandør av subsea-utstyr til oljeindustrien, som en leverandør av utstyr til olje- og gass-sektoren, eller som en utstyrsleverandør i industri.

Det at den objektive tolkningen skal ha særlig tyngde ved tolkning av forhandlede standardkontrakter, kan dermed også forstås som et spørsmål om den faktiske referanserammen for tolkningen er mer generell og abstrahert enn ved tolkning av individuelle avtaler. I så fall vil tolkningsresultatet i større grad bli likt selv om avtaleteksten brukes i ulike konkrete forhold.

Huser og Hellner har diskutert dette. Huser diskuterer om det ved tolkning av standardkontrakter bør legges til grunn et standardisert faktum, slik at en ser bort fra partenes individuelle kunnskap og behandler ordlyden omtrent som en lovtekst, men finner ikke er grunnlag for det i norsk rett. ${ }^{71} \mathrm{Hellner}$ argumenterer for at det særlig ved tolkning av masseavtaler som forsikringsavtaler, der det er stor ulikhet i forhandlingsstyrke mellom partene, bør ses bort fra individuelle omstendigheter. Hellner anbefaler en lovtolkningslignende metode der «Avtalets formulering och allmänna ändamålsöverväganden som går ut på att finna en lämplig regel» bør stå i forgrunnen. ${ }^{72}$

Hellners diskusjon har bakgrunn i at det i tysk rett har utviklet seg to teorier om tolkning av standardvilkår lovtolkningsmetoden og avtalemetoden. Lovtolkningsmetoden går ut på å tolke standardkontrakter omtrent som lover, uten særlig hensyn til individuelle momenter. I tysk rett har nok imidlertid tolkningsresultatene av de to metodene stadig nærmet seg hverandre. ${ }^{73}$ De tyske teoriene har ikke satt særlig synlige spor etter seg i nordisk rettspraksis.

Etter mitt syn er dette i praksis ikke et spørsmål om enten - eller, men et spørsmål om $i$ hvilken grad den faktiske referanserammen for tolkningen er standardisert. Et naturlig utgangspunkt er kontrakten

\footnotetext{
${ }^{68}$ Se Rt-2007-1489, avsnitt 74 og Rt-2014-866 avsnitt 43 (begge anbudsrett) og Rt-1997-1807, på s. 1813 (forsikringsrett).

${ }^{69}$ Ramberg og Ramberg 2016, s. 42. Tilsvarende i PECL Art. 5:101 (1) jf. (3) og UNIDROIT Principles 2010 Art. 4.1, DCFR II-4:102.

${ }^{70}$ Lilleholt 2017, s. 104.

${ }^{71}$ Huser 1983 s. 470-472.

72 Jan Hellner, Tolkning av standardavtal, JV 1994 s. 266, særlig s. 267 og 277. Sitat fra s. 278.

${ }^{73}$ Se Geir Woxholth, Avtalerett, 2017 s. 442-443.
} 
selv. De største standardkontraktene angir hvilket område de er utarbeidet med tanke på. NS 8405 er utarbeidet med sikte på bruk i «kontraktsforhold hvor én part (entreprenøren) påtar seg utførelsen av et bygg- eller anleggsarbeid (herunder anlegg, nybygg, vedlikehold, reparasjon og ombygging) for den andre parten (byggherren), og hvor det vesentlige av tegninger, beskrivelser og beregninger skal leveres av byggherren.» (art. 1). Fabrikasjonskontraktene er knyttet til offshoresektoren, for eksempel er NTK 15 anbefalt brukt for «kontrakter om leveranse av større komponenter til produksjon av petroleumsforekomster på norsk sokkel der leverandøren skal stå for prosjektering, innkjøp, bygging og eventuelt installasjon (EPC(1))». Det påtenkte anvendelsesområdet for kontraktene viser i hvilke situasjoner bransjeorganisasjonene har oppfattet at likeartede spørsmål ville oppstå. Når aktørene selv oppfatter at de opererer innen samme område, vil utstrakt bruk av kontraktene føre til at aktørene opparbeider erfaring med bruken av dem. Denne «profesjonaliseringen» av partene med utgangspunkt i kontraktene selv kan føre til at tolkningen av kontraktene generaliseres, fordi den blir retningsgivende for den tenkte tredjeparts kunnskap og forventning.

For øvrig må eventuelle slutninger utledes fra hvordan Høyesterett i konkrete saker fastlegger den faktiske referanserammen for tolkningen. Da må en se på hvilke «briller» Høyesterett tar på seg $\mathrm{i}$ tolkningsprosessen. Rt-2014-520, Repstad anlegg, gjaldt tolkningen av en enhetspriskontrakt om sanering av et vann- og avløpsanlegg. Spørsmålet var om en reduksjon i regulerbare mengder i forhold til det stipulerte kunne gi grunnlag for avbestillingserstatning etter NS 8406:2009 pkt. 28. I avsnitt 35 uttaler Høyesterett:

«(...) I enhetspriskontrakter av denne art ligger det innbakt i selve kontraktsmekanismen at faktisk medgåtte mengder vil avvike fra de stipulerte. Avvikene kan regelmessig være betydelige, noe som er vel kjent blant aktørene. En fremlagt oversikt over forskjellige anleggsarbeider utført etter oppdrag fra Arendal kommune er i så måte illustrerende. Faktisk vederlag har variert mellom 78 og 161 prosent av kontraktssummen i elleve prosjekter basert på enhetspris og regulerbare mengder. Større eller mindre avvik er med andre ord normalsituasjonen i slike kontrakter.»

Muligens kan dette forstås slik at det avgjørende ikke er å finne en tilsvarende entreprenør innen sanering av vann- og avløpsanlegg, som var det arbeidet kontrakten gjaldt, men å se på forhold der denne typen kontrakt blir brukt og der det samme tolkningsspørsmålet kan oppstå. Poenget er å definere den tenkte tredjepart som kommunen kan forvente å forholde seg til.

Tolkningen av standardkontraktene skiller seg på dette punkt fra individuelt forhandlede kontrakter. Ved tolkning av en individuelt forhandlet kontrakt glir den objektive tolkningen av ordlyden og tolkningen som går ut på å finne frem til partenes felles mening over i hverandre, fordi teksten er resultatet av konkrete forhandlinger, og de forhandlingene inngår i hvordan en tenkt tredjepart med rette kan oppfatte vilkårene. For standardkontraktene, er ordlyden ikke så tett koblet til de konkrete forhandlingene, og bransjen opparbeider seg en felles erfaring med kontraktene som inngår i 
forutsetningene for hvordan aktørene med rette kan oppfatte vilkårene. Det legger til rette for en mer generalisert og abstrahert tolkning. Dermed ligger det også til rette for at det kan dannes egne «kontraktsretter» med utgangspunkt i de store standardkontraktene (se avsnitt 4.2.3).

\section{Tolkning av ordlyden med «objektiv slagside»}

\subsection{Andre objektive tolkningsargumenter}

Tolkningen av standardkontrakter er ikke begrenset til ordlydstolkning, jf. HR-2016-1447-A, Norsk Gjenvinning, avsnitt 42. Ordlyden må «(..)leses i lys av de formål de skal ivareta, og andre reelle hensyn». ${ }^{74}$ Tolkningen er objektiv, siden tolkningsargumentene utledes fra kilder som ikke er knyttet til oppfatningene hos partene. ${ }^{75}$ I norsk tolkningslære er det liten tradisjon for å sette grenser for hvilke tolkningsargumenter som er relevante, slik at den reelle diskusjonen er hvilken vekt en skal legge på tolkningsargumenter utenfor ordlyden selv.

I svensk rett har teorien, på bakgrunn av praksis fra Högsta domstolen, gjerne satt opp tolkningsargumentene hierarkisk, slik at argumentenes relevans og vekt følger listen. Bernitz setter argumentene i denne rekkefølgen: 1) partenes omforente vilje, 2) klargjørende omstendigheter omkring avtalen, 3) kontraktens ordlyd, 4) avtalens systematikk, og 5) bakgrunnsretten. ${ }^{76}$ I nyere praksis om standardavtaler, har Högsta domstolen inkludert en rimelighetsvurdering som pkt. 6). ${ }^{77}$ Norsk Høyesterett følger oftest en mer pragmatisk metode, der tolkningen knyttes til de argumentene som gjør seg gjeldende i den konkrete sak. Et unntak er Rt-2005-788, omtales straks nedenfor. Tolkningsresultatene er nok ikke så forskjellige, men formuleringen av en generell tolkningslære overlates mer til teorien.

Hensynet til sammenheng i avtalen tillegges stor vekt i all kontraktstolkning. ${ }^{78}$ De forhandlede standardkontraktene er også skrevet av profesjonelle personer med betydelig innsikt i saksområdet, og de risikoavveiningene kontraktene som helhet legger opp til, kan være uttrykk for kompromisser på bransjenivå. ${ }^{79} \mathrm{Om}$ standardavtalen nyter stor tilslutning i bransjen, forsterkes disse argumentene. ${ }^{80}$

Hensynet til sammenheng henger nært sammen med en vurdering av konsekvensene for partene av de ulike tolkningsalternativene. Et eksempel er Rt-2014-520, Repstad Anlegg. Høyesterett mente at NS 8406 (2009) pkt. 28.3 om avbestilling måtte tolkes i sammenheng med pkt. 19.1 om endringer og justering av vederlag: Et mengdeavvik som ikke var «vesentlig» nok til å justere vederlaget, burde heller ikke kunne gi grunnlag for avbestilling (avsnitt 36-38). En henvisning til sammenheng i avtalen,

\footnotetext{
${ }^{74}$ Rt-2010-961, avsnitt 44, gjentatt i Rt-2012-1729 avsnitt 67 og Rt-2014-866 avsnitt 42.

${ }^{75}$ Se Bernitz 2013, s. 87.

${ }^{76}$ Bernitz 2013, s. 94-95 som viser til NJA 2012 s. 597.

77 Jf. NJA 2014 s. 960 og NJA 2015 s. 862.

78 Jf. Rt-2014-520, avsnitt 36, HR-2016-1447-A avsnitt 43, NJA 2007 s. 35. Se også UNIDROIT Principles 2010 Art. 4.4 og PECL 5:105.

${ }^{79}$ Jf. Rt-2000-806 på s. 815, Knut Kaasen, Petroleumskontrakter med kommentarer til NF 05 og NTK 05, 2006, s. 50, Helge Jacob Kolrud m.fl., NS 8405 Kommentarutgave, 2004 s. 42-43 og Bernitz 2013, s. 93-94.

${ }^{80}$ Se Rt-1986-1386 der NS 3401 brukes for å tolke individuelt utformede standardvilkår
} 
kan derfor romme argumenter som også kan rubriseres som reelle hensyn. Selv om, som jeg kommer tilbake til nedenfor, det i en tolkningssituasjon der den objektive tolkningen skal ha særlig gjennomslag, kan være lite rom for argumenter av typen reelle hensyn, er det ikke sikkert at tolkningsresultatet blir vesentlig annerledes for det. Også innenfor de objektive tolkningsargumentene er det rom for valg mellom tolkningsløsninger, der valget kan være preget av rettsanvenderens vurdering av resultatet i den konkrete sak.

\subsection{Forholdet til bakgrunnsretten}

\subsubsection{Bakgrunnsretten som tolkningsargument}

«Bakgrunnsrett» omfatter den deklaratoriske kontrakts-, kjøps- eller entrepriseretten. ${ }^{81}$

Tolkningsargumentene som hentes derfra, er legitimert gjennom samfunnets kontroll med avtalers innhold. Som tolkningsargument bidrar bakgrunnsretten til forutberegnelighet ved at tolkningsresultatet trekkes mot bakgrunnsrettens normalløsninger. Bakgrunnsretten er derfor i utgangspunktet et tungtveiende tolkningsargument. ${ }^{82}$ Spørsmålet er om det ved tolkning av forhandlede standardkontrakter skal mindre til for å fravike bakgrunnsrettens løsning enn ved tolkning av individuelle avtaler. Dette er knyttet til situasjonen med et «overskudd» av objektive tolkningsargumenter som beskrevet i pkt. 1.2. Spesielt for standardkontraktene er at det kan finnes tidligere tolkningsavgjørelser eller argumenter fra avtalens tilblivelseshistorie som taler for å forstå ordlyden slik at den fraviker bakgrunnsrettens løsning. Alle disse tolkningsargumentene vil bidra til å fremme forutsigbarhet, fordi de trekker mot samme tolkningsresultat hver gang avtalen brukes. Diskusjonen videre gjelder den nærmere nyanseringen av et slikt hensyn til forutsigbarhet.

\subsubsection{Tidligere tolkningsavgjørelser}

Det er svært sjelden at domstolene viser til tidligere tolkningsavgjørelser om konkrete tolkningsresultater. Huser legger til grunn at tidligere dommer om tolkningen av en avtale, og standardkontrakter især, kan være relevante ved senere tolkninger av samme ordlyd. ${ }^{83}$ Forutsetningen er at tolkningstilfellene er tilstrekkelig like, altså at det ikke bare er samme standardavtale som er gjenstand for tolkning, men at den faktiske rammen for tolkningen også er tilstrekkelig lik. ${ }^{84}$ Det innebærer for det første at det vanskelig kan legges noen vekt på tidligere tolkningsuttalelser innenfor den partsspesifikke tolkningen. For det andre må den faktiske referanserammen for den objektive

\footnotetext{
${ }^{81}$ «Bakgrunnsretten» er relevanskriteriet for hvilke rettsregler som kan gi grunnlag for utfylling av privatrettslige avtaler. Se min artikkel «Konkurranserettens betydning ved tolkning og utfylling av avtaler», TfR, 2016, s. 372 og Høgberg 2006, s. 173 flg. Bakgrunnsretten omfatter også andre rettsregler, både privatrettslige regler som husleieloven, se HR-2016-1447-A, og offentligrettslige regler som vassdragsreguleringsloven, se Rt-2000-806.

${ }^{82}$ Se NOU 1976:61 s. 62, Bernitz 2013, s. 90 og NJA 2013 s. 271.

${ }^{83}$ Huser, 1983 s. 531 flg.

${ }^{84}$ Jf. Huser 1983, s. 536. Han viser til Rt-1971-1305 og Rt-1959-777. Saksforholdet er kuriøst: Høyesterett tolket samme leieavtale i to ulike leieforhold i samme bygård.
} 
tolkningen være lik nok, jf. pkt. 3. Det vil antagelig være svært sjelden at omstendighetene er så like at en kan bygge direkte på den tidligere tolkningsuttalelsen.

Ett av få eksempler, er Rt-2005-788, hvor Høyesterett viser til en voldgiftsdom om samme standardkontrakt. Saken gjaldt tolkningen av uttrykket «merutgifter» i pkt. 21.1 i NS 3430, etter at byggingen av Oslofjordtunnelen var blitt forsinket som følge av løsmasser i tunneltraseen. Høyesterett så på ordlyden (avsnitt 43), konsekvensene for partene (avsnitt 44-45), rimelighetshensyn (avsnitt 46) og rettstekniske hensyn (avsnitt 47), og først deretter tok Høyesterett opp voldgiftsdommen (avsnitt 48). Tolkningsargumentet fra voldgiftsdommen synes derfor å ha blitt tillagt relativt liten vekt.

Rt-2005-268, Pan Fish, gjaldt en avtale om slakting av laks. Høyesterett (avsnitt 55), avviste å legge vekt på en tidligere høyesterettsdom (Rt-1970-1350), om tolkning av en lignende avtale i relasjon til et tilsvarende misligholdsspørsmål. Selv om det var faktiske likhetstrekk mellom sakene, var det også vesentlige forskjeller. Dessuten viste Høyesterett til at bakgrunnsretten antagelig hadde utviklet seg siden den tidligere avgjørelsen, ved at hensynet til lojalitet i kontraktsforhold var blitt tillagt $\varnothing$ kende vekt. Avtalen var individuelt forhandlet, men de samme argumentene gjør seg gjeldende ved tolkning av standardkontrakter. ${ }^{85}$

I praksis får tidligere tolkningsavgjørelser adskillig betydning for tolkningen, selv om de ikke er synlige som argumenter i domstolenes avgjørelser. Avgjørelser som Rt-2014-520, Repstad anlegg, om sammenhengen mellom reglene om avbestilling og justering av vederlaget ved mengdeavvik, NS 8604:2009 pkt. 28.3 jf. pkt. 19.1, vil lett absorberes i bransjens oppfatning av hvordan vilkårene skal forstås. ${ }^{86}$ Konsekvensen er at samme tolkningsspørsmål ikke kommer opp for domstolene igjen.

Etter mitt syn er tolkningsargumenter hentet fra bakgrunnsretten som hovedregel bedre egnet til å fremme forutberegnelighet enn tidligere tolkningsavgjørelser. Bakgrunnsretten vil trekke mot det samme tolkningsresultatet uansett om de faktiske forholdene avtaleteksten er brukt for, er forskjellige. Dessuten vil bakgrunnsretten som tolkningsargument bedre fange opp at kontraktsretten er dynamisk. Tidligere tolkningsavgjørelser er statiske. Fordi særlig den deklaratoriske kontraktsretten endres i samspill med bruken av de største standardkontraktene, er også partenes forventninger i forhold til

\footnotetext{
${ }^{85}$ Andreas Meidell, «Standardvilkår som uniforme regler for internasjonale kontrakter: En introduksjon», Jussens Venner, 1999 s. 399, har undersøkt brukt tidligere tolkningsavgjørelser i internasjonal voldgiftspraksis, men finner ikke at domstolene viser til tidligere tolkningsavgjørelser.

${ }^{86}$ De aktuelle bestemmelsene i standarden ble endret.
} 
standardkontraktene dynamiske. Det fanges etter mitt syn bedre opp ved å legge vekt på bakgrunnsretten enn ved å legge vekt på tidligere tolkningsavgjørelser. ${ }^{87}$

For noen av standardkontraktene er imidlertid avstanden til bakgrunnsretten så stor at den gir mindre veiledning i tolkningen. I så fall må nok dette utgangspunktet modifiseres. Ved tolkningen av skipsbyggingskontrakter, er det begrenset veiledning å hente i kjøpsloven. Det fører til at det raskere danner seg mer spesialiserte oppfatninger som etter hvert blir spesiell kontraktsrett. Befraktningsretten er et eksempel på det, se Rt-2013-129, Normar Fish, om NSABs status som uttrykk for sedvanerett.

\subsubsection{Standardkontraktens plass i bakgrunnsretten}

I noen tilfeller kan det være vanskelig å skille klart mellom kontraktsteksten og bakgrunnsretten, og da oppstår spørsmålet om standardkontraktens løsninger er uttrykk for spesiell kontraktsrett. ${ }^{88}$ Det betyr at ordlyden kan få en utvidet legitimasjon i tolkningen, fordi den også er uttrykk for bakgrunnsrett. ${ }^{89}$

Dette henger sammen med diskusjonen om det eksisterer «spesielle kontraktsretter» med utgangspunkt i de største standardkontraktene..$^{90}$ Den alminnelige kontraktsretten har utviklet seg gjennom de spesielle kontraktsformene, og det er ikke tette skott mellom eksempelvis entrepriserett, fabrikasjonsrett og generell kontraktsrett. Enkeltspørsmål kan ha fått særlige løsninger på begrensede områder, og denne utviklingen kan være støttet på og dels drevet av, utviklingen av de store standardkontraktene. ${ }^{91}$ Slik blir standardkontraktene en del av rettsutviklingen på sitt område. Mindretallet i Rt-2010-1345, Oslo Vei, avsnitt 75, er inne på dette:

«Ved tolking av standardkontrakter, vil det være mindre rom for individuelle tolkingsmomenter, og jeg er enig i at det vil være nærliggende å legge stor vekt på ordlyden. Når det gjelder standarder med stor utbredelse, som har vært benyttet over lang tid, vil det imidlertid på ulike punkter ha kunnet danne seg allment aksepterte tolkinger av standarden, som da må legges til grunn. Det kan i det minste ha blitt avklaret gjennom praksis at ulike bestemmelser i standarden ikke kan tas på ordet. Dette er en høyst aktuell problemstilling ved tolkingen av NS-3430.»

En slik «dobbel» legitimitet i teksten kan være bakgrunnen for at teorien av og til legger til grunn at bakgrunnsretten er en nødvendig kilde for utfylling av spørsmål som kontrakten ikke selv regulerer, men har mindre betydning der standardkontraktene er utførlige. ${ }^{92}$ Det betyr at kutymer eller

\footnotetext{
${ }^{87}$ Slik Amund Bjøranger Tørum, «Sammenlignende analyser av fabrikasjon og entreprise - illustrert med endrings- og varslingsreglene og arbeidsplikten», i Jan Einar Barbo og Lasse Simonsen (red.), På rett grunn, Festskrift til Norsk Forening for Bygge- og Entrepriserett, 2010, s. 453 på s. 458 til 460. Motsatt Erlend Haaskjold, Kontraktsforpliktelser, 2013 s. 416.

${ }^{88}$ Se Lilleholt 2017, s. 120.

${ }^{89}$ Se Nils Nygaard, Rettsgrunnlag og standpunkt, 2004 s. 337. Jf. pkt. 2.3.2.3.

${ }^{90}$ Se Knut Kaasen, Petroleumskontrakter med kommentarer til NF 05 og NTK 05, 2006 s. 53-54.

${ }^{91}$ Standardkontraktene kan ha løsninger som er brukt så mye at de får status som typeløsninger, naturalia negotii; se Rt1978-1157. Se Bert Lehrberg, Avtalstolkning, 2014, s. 144, Kai Krüger, Kontraktsrett, 1989 s. 528, Bernitz 2013, s. 59.

${ }^{92}$ Se Amund Bjøranger Tørum, «Sammenlignende analyser av fabrikasjon og entreprise - illustrert med endrings- og varslingsreglene og arbeidsplikten», i Jan Einar Barbo og Lasse Simonsen (red.), På rett grunn, Festskrift til Norsk Forening
} 
kontraktstypeløsninger som har dannet seg rundt standardens ordlyd, gjerne støttet på rettspraksis, som tolkningsargument har legitimitet og vekt som bakgrunnsrett. Konsekvensen av det er at det blir svært vanskelig å komme frem til tolkningsresultater som fraviker ordlyden, fordi ordlyden sammenfaller med bakgrunnsretten. Slik utvikling skjer over tid, og spørsmålet om ordlyden også er uttrykk for kontraktsrett, må avgjøres konkret.

Det at standarden er en del av bakgrunnsretten, kan føre til at terskelen blir lav for å anse standarden som vedtatt. Et eksempel er LB-1997-3165, der partene i en individuell avtale henviste til «relevante norske standarder». Lagmannsretten kom til at partene med det hadde vedtatt at NS 3431 var del av avtalevilkårene. Resultatet ble motsatt i Rt-2004-675, Agurkpinne, der selger hadde tatt inn en ansvarsbegrensning i sluttseddel sendt med fraktbrev. Vilkåret ville innebære en vesentlig risikooverføring fra selger til kjøper i forhold til kjøpslovens regler. Selv om klausulen var hentet fra lignende avtaler i bransjen, var den ikke uttrykk for noen kontraktstypeløsning, og forholdet måtte løses etter kjøpslovens regler.

\subsubsection{Skal det mindre til å fravike bakgrunnsretten?}

Svaret på spørsmålet om det skal mindre til å fravike bakgrunnsretten i forhandlede standardkontrakter enn i individuelle avtaler, er etter mitt syn nokså klart nei. Bakgrunnsretten som tolkningsargument fremmer forutberegnelighet, både for de konkrete partene og i et videre perspektiv, og tar høyde for at rettsutviklingen kan skje i sammenheng med de store standardkontraktene.

Domstolenes konkrete avtaletolkning er resultat av de argumentene som gjør seg gjeldende i den konkrete saken. Domstolen vil nok også ha en oppfatning om konsekvensene av de ulike tolkningsalternativene. Muligens kan bakgrunnsretten gi domstolen tolkningsverktøy som er mer fleksibelt enn de mer statiske og stiliserte argumentene fra tidligere tolkningsavgjørelser og forhandlingsdokumentasjon. Bakgrunnsretten gir allment aksepterte, og sanksjonerte, løsninger som oppfattes som balanserte og rimelige. Henvisning til bakgrunnsretten kan derfor være et kompass for å styre resultatet i retning av det som oppfattes som balansert eller rimelig i det konkrete tilfellet.

Dette kan illustreres ved domstolenes bruk av den ulovfestede lojalitetsplikten i tolkning og utfylling av standardkontrakter. Lojalitetspliktens begrunnelse er å sikre en fornuftig gjennomføring av den konkrete avtalen, og et viktig nedslagsfelt er å gi grunnlag for løsninger som er mangelfullt regulert $\mathrm{i}$ kontrakten, men som må løses for å gjennomføre den. ${ }^{93}$ Lojalitetsstandarden kan gi grunnlag for en medvirkningsplikt for at kontraktsmotparten skal kunne gjennomføre sine plikter eller ivareta sine interesser. ${ }^{94}$ I Rt-2011-65, åpnet Høyesterett for at lojalitetsplikten kunne gi grunnlag for en plikt til å

for Bygge- og Entrepriserett, 2010, s. 453 på s. 458 til 460, Knut Kaasen, Petroleumskontrakter med kommentarer til NF 05 og NTK 05, 2006 s. 53-54. Se Rt-1978-1157, på s. 1160, og LB-2010-174847, der lagmannsretten viste til bustadoppføringsloven $\S 16$ for utfylling av NS 8405.

${ }^{93}$ Eksempler i Rt-2005-268 og NJA 2010 s. 416. Se videre Jori Munukka, Kontraktuell lojalitetsplikt, 2007 s. 1 og Henriette Nazarian, Lojalitetsplikt i kontraktsforhold, 2007 s. 29.

${ }^{94}$ Se Hans-Jørgen Arvesen m.fl., NS 8406 Forenklet norsk bygge- og anleggskontrakt med kommentarer, 2014, s. 147 og 157. 
varsle byggherren om et krav om tilleggsvederlag for endret prosjekteringsarbeid under NS-8401. ${ }^{95}$ Dermed gir bakgrunnsretten domstolen et verktøy for en tilpasning i forhold til en streng ordlydstolkning, som de spesielle objektive argumentene (tidligere tolkningsuttalelser og tilblivelseshistorien) i mindre grad åpner for. Tolkningen er like fullt objektiv, i den forstand at den beror på argumenter som ikke er spesielle for de konkrete partene.

\subsection{Standardavtalens tilblivelseshistorie}

\subsubsection{Kan forhandlernes mening supplere partenes mening?}

Dokumentasjon fra bransjerepresentantenes forhandlinger gir en kilde for tolkningsargumenter som er spesielle for standardkontraktene. Slike «forarbeider» kan være brev- og meningsutvekslinger, forhandlingsprotokoller, kommentarer ${ }^{96}$ eller forklaringer fra personer som deltok i forhandlingene. ${ }^{97}$ Her er spørsmålet om forhandlernes vilje, dokumentert gjennom beviser fra avtalens tilblivelse, kan supplere partenes vilje i tolkningen. Dette er et spørsmål om hvilken legitimitet «forarbeidene» har som tolkningsargument. Argumentets vekt, herunder betydningen av om forhandlingsdokumentasjonen er allment tilgjengelig, behandles i pkt. 4.3.2.

Spørsmålet kan belyses ved å sammenligne tolkning av forhandlede standardkontrakter med lovtolkning. ${ }^{98}$ Ved tolkning av lover belyser lovforarbeidene lovgivers vilje eller formål med lovreguleringen. Argumenter fra lovforarbeidene bidrar til å fremme forutsigbarhet fordi forarbeidene er tilgjengelige for alle. Når vi søker lovgiverviljen, er det et argument som er legitimert gjennom lovgivers kompetanse til å regulere området. I avtaletolkning er det imidlertid partene som gjennom sin felles vilje binder domstolen, legitimert gjennom privatautonomien. Når partene bruker standardkontrakten, er det ut fra et $\varnothing n s k e$ om forutsigbarhet. Det er vanskelig å tenke seg at partene bevisst $\varnothing$ nsker å tilslutte seg forhandlernes vilje bak kontraktsvilkårene - i den grad denne ikke er kommet klart til uttrykk i avtaleteksten. I forhold til forarbeidsbruk ved lovtolkning svikter altså grunnlaget for å vektlegge forhandlingsdokumentasjon som gjelder forhandlernes vilje eller intensjon, så fremt denne ikke er kommet til uttrykk i avtaleteksten. Det vil etter mitt syn kun være legitimt å vektlegge forhandlingsdokumentasjon ut fra hensynet til forutsigbarhet. ${ }^{99}$ Dette hensynet kan riktignok

\footnotetext{
${ }^{95}$ Rt-2011-65 avsnitt 43, og LB-2003-19361.

${ }^{96}$ Som kommentaren til Sjøforsikringsplanen, se http://www.nordicplan.org/Commentary/. (sist besøkt 14. mai 2018).

${ }^{97}$ Jf. Rt-1948-329 og Rt-1969-126.

${ }^{98}$ Se Hans Jacob Bull, «Avtalte standardvilkår som privat lovgivning», i Lov, dom og bok: Festskrift til Sjur Brckhus, 1988 s. 99 flg. om tolkningen av Sjøforsikringsplanen.

${ }^{99}$ Sml. Thor Falkanger, «Tolkning av sjørettslige standardkontrakter - særlig om betydningen av forarbeider», Ånd og rett Festskrift til Birger Stuevold Lassen, 1997, s. 289 flg. på s. 293. Han skiller ikke mellom forhandlernes vilje og forhistorien som kilde til argumenter som fremmer forutsigbarhet.
} 
tillegges en del vekt, men det kan ikke få den forrang i tolkningen som partenes vilje har i kraft av privatautonomien.

I Rt-1998-1032, Lomita, om tolkningen av Sjøforsikringsplanen, viste Høyesterett til Brækhus og Rein, "Håndbok i kaskoforsikring", Oslo 1993 side 8, som argumenterte for at kommentarene til Sjøforsikringsplanen er en del av planen fordi de ble godkjent av den komitéen som reviderte Sjøforsikringsplanen. Denne argumentasjonen innebærer at kommentarene «rykker oppover» i tolkningsargumentenes vekthierarki og får samme status som avtalens ordlyd. Fordi Høyesterett ikke fant at forhandlerne hadde hatt noen mening om det aktuelle spørsmålet, kom ikke vektspørsmålet på spissen. ${ }^{100}$

En konkret variant av spørsmålet, kan komme opp dersom forhandlerne har sin bakgrunn i utenlandsk, typisk engelsk rett, og har skrevet kontrakten på engelsk. Så lenge norsk rett regulerer avtalen, og partene ikke har avtalt noe om betydningen av at avtalen er skrevet på engelsk, ${ }^{101} \mathrm{er}$ det norsk tolkningslære som gjelder. ${ }^{102}$ Da skal ordlyden tolkes slik en normalt aktsom part under tilsvarende omstendigheter ville forstå den. ${ }^{103}$ Engelske juridiske begreper vil ikke uten videre bli tolket som i engelsk materiell rett. ${ }^{104}$ Spørsmålet er om en ved tolkning av forhandlede standardkontrakter likevel kan legge vekt på hva forhandlerne mente med engelske juridiske begreper i teksten, fordi dette er en del av avtalens tilblivelseshistorie.

På den ene siden vil en tolkning med vekt på forhandlernes utgangspunkt i engelsk rett, åpne for en mer internasjonal tolkning som også inkluderer kilder som PECL, UNIDROIT Principles eller CISG. ${ }^{105}$ På den annen side, vil en slik tolkning nettopp vise konsekvensene av å legge vekt på forhandlernes vilje som et selvstendig argument når denne viljen er uttrykt på engelsk og dermed ikke følger med ordlyden inn i norsk tolkningslære. Forhandlernes vilje rykker i så fall oppover i tolkningsargumentenes vekthierarki, og går foran partsautonomien, altså den naturlige forståelsen av

\footnotetext{
${ }^{100}$ Svensk Høyesterett har i en avgjørelse fra 4. mai 2018, T 3671-17, Green Cargo AB, uttalt seg i retning av at Jan Ramberg og Tom Rune Nilsens kommentar til NSAB kan tillegges vekt foran tolkningsargumenter utledet fra dispositiv bakgrunnsrett. ${ }^{101}$ I forordet til NF 15 og NTK 15, fremgår at den norske språkversjonen har forrang foran den engelske. Dette ville også fulgt av alminnelige tolkningsprinsipper, se UNIDROIT Principles 2010 Art. 4.7 og Art. 5:107 PECL, Bernitz 2013 s. 87. ${ }^{102}$ Sml. Erlend Haasjold, Kontraktsforpliktelser, 2013, s. 420 jf. s. 195 som, slik jeg forstår ham, mener at dette er et argument for en striktere ordlydstolkning.

${ }^{103}$ Se Rt-2012-1267 avsnitt 48 til 56 jf. avsnitt 70, om tolkning av en garantierklæring skrevet på engelsk. Et illustrerende eksempel i LF-2016-40317. I et garantidokument sto det: «(...)hereby unconditionally and irrevocably guarantee in favour of the Beneficiary as and for our own debt (No: som selvskyldner) upon his demand (...)». Garantien ble likevel tolket som en påkravsgaranti, fordi den polske kontraktsparten ikke forsto hva den tilføyde norske termen betydde.

104 Jf. Erling Selvig, «Tolking etter norsk eller annen skandinavisk rett av certepartier og andre standardvilkår utformet på engelsk», TfR, 1986 s. 1, på s. 4. På sjørettens område kan en kanskje si at engelske rettslige termer inngår i «bransjespråket», jf. Anders Mikelsen, «Henvisninger til engelsk rett i kontrakter underlagt norsk rett», TfR, 2008 s. 532 på s. 543, og Trond Solvang, Forsinkelse i havn, 2009 s. 105 flg.

${ }^{105}$ Se Andreas Meidell, «Standardvilkår som uniforme regler for internasjonale kontrakter: En introduksjon», Jussens Venner, 1999 s. 399.
} 
teksten for de konkrete partene. Det vil etter mitt syn bryte med partsautonomiens forrang. I norsk praksis er det heller ingen spor av slik argumentasjon. ${ }^{106}$

Til sammenligning, synes det i svensk rett å være mindre tradisjon for å vektlegge kilder fra standardens tilblivelseshistorie. Domstolene kan innhente tolkningsuttalelser fra Byggandets Kontraktskomité (BKK), se for eksempel NJA 2007 s. 35, NJA 2014 s. 960 og NJA 2015 s. 3. Uttalelsene kan være kilde til informasjon om bransjepraksis eller gi uttrykk for bransjeaktørers oppfatninger. Nyere svensk praksis oppfattes i teorien slik at argumenter fra bransjepraksis og generelle reelle hensyn inngår i en rimelighetsvurdering som er sekundær til de øvrige tolkningsargumentene. ${ }^{107}$ På samme måte behandles slike uttalelser i norsk rett, jf. for eksempel Rt2003-1531, Veidekke, avsnitt 43-44, der Høyesterett siterer en uttalelse fra Byggebransjens Faglig Juridiske Råd, og presiserer at det er et argument i kategorien reelle hensyn.

\subsubsection{Hvilken vekt kan legges på argumenter utledet av standardens tillblivelseshistorie?}

Det er altså hensynet til forutberegnelighet som legitimerer at avtalens tilblivelseshistorie tillegges vekt. Hvilken vekt, må avgjøres konkret. For det første er argumentenes vekt avhengig av konkrete forhold ved de aktuelle «forarbeidene». ${ }^{108}$ Det er lettere å legge vekt på forarbeider som er tilgjengelige for partene, fordi de kan gi grunnlag for berettigede forventninger om hvordan avtalens ordlyd er å forstå. ${ }^{109}$ Det er stor forskjell mellom standardkontraktene med hensyn til hvor klare, representative og tilgjengelige eventuelle forarbeider er. Etter mitt syn må det avgjørende være i hvilken grad argumentet konkret fremmer hensynet til forutberegnelighet.

Argumenter utledet fra kilder som ikke er offentlig tilgjengelige, bør derfor få liten vekt. Partene kan ikke forutberegne sin rettsstilling med grunnlag i kilder de ikke har tilgang til. ${ }^{110}$ Muntlige uttalelser fra forhandlerne, er enda mindre tilgjengelige, se Rt-1969-126, Grethe Solheim. ${ }^{111}$ I tillegg har slike uttalelser nødvendigvis et subjektivt preg og kan gå ut på forklaringer om hva man oppfattet under

\footnotetext{
${ }^{106}$ Jf. Rt-2012-1267. Heller ikke i internasjonal voldgiftspraksis, se Andreas Meidell, «Standardvilkår som uniforme regler for internasjonale kontrakter: En introduksjon», Jussens Venner, 1999 s. 399.

${ }^{107}$ Se Isak Willborg, «Högsta domstolens tolkning av entreprenadavtal», Juridisk Tidskrift, nr. 4 2016/17, s. 864, og Anders Ingvarson og Marcus Utterström, «Högsta domstolens intåg i entreprenadrättens slutna rum», SvJT, 2015 s. 258, sml. Bernitz 2013, s. 95. Jeg oppfatter at Bernitz ikke har med disse momentene i listen over tolkningsmomenter, fordi han mener de vil ha helt underordnet betydning for tolkningen.

108 Bernitz 2013, s. 95.

${ }^{109}$ Se Jan Hellner, «Tolkning av standardavtal», JV, 1994 s. 266 på s. 273-274, Kai Krüger, Norsk Kontraktsrett, 1989, s. 519

og Thor Falkanger, «Tolkning av sjørettslige standardkontrakter - særlig om betydningen av forarbeider», Ånd og rett -

Festskrift til Birger Stuevold Lassen, 1997, s. 298 flg. på s. 301-302.

${ }^{110}$ Sml. Rt-1991-719, Hardhaus.

${ }^{111}$ Se Hans Jacob Bull, «Avtalte standardvilkår som privat lovgivning», i Lov, dom og bok: Festskrift til Sjur Brcekhus, 1988 s. 99 flg. på s. 110 .
} 
forhandlingene. Som diskutert over, mener jeg det er vanskelig å finne et legitimt grunnlag for å legge vekt på «forhandlerviljen»slik man legger vekt på lovgivers vilje ved bruk av forarbeider i lovtolkningen. Det betyr at muntlige uttalelser om at noe $i k k e$ ble diskutert under forhandlingene, kanskje er de mest nyttige. Da er det lettere å være enig i Høyesteretts henvisning til forklaringer fra forhandlerne i Rt-1998-1032, Lomita.

For det andre er argumentets innhold av betydning for hvilken vekt det tillegges. I Rt-1991-719, Hardhaus, viste Høyesterett til uttalelser i brev fra forhandlerne av en standardisert verkstedkontrakt. Poenget var å belyse hvor langt de forhandlende parter hadde vært omforent om forståelsen av de begreper som ble brukt, og hvilke spørsmål de ulike sidene i bransjen hadde vært opptatt av. Høyesterett har også lagt vekt på hvordan standarden har utviklet seg, jf. Rt-2014-520, Repstad anlegg, avsnitt 33 og 34. ${ }^{112}$ I HR-2016-1447-A, så Høyesterett på endringer av bakgrunnsretten (husleielovgivningen), og parallelle revisjoner av standardkontrakten. ${ }^{113}$ Høyesterett viste til tidligere husleielover som forutsatte at leietaker måtte ha misligholdt leieavtalen for å bli erstatningsansvarlig overfor utleier. Når tidligere versjoner av standarden ikke hadde fraveket loven (avsnitt 48-53), var det naturlig å oppfatte gjeldende versjon å forholde seg til loven på samme måte (avsnitt 54-57).

I disse sakene brukes forhistorien til å belyse oppfatninger som er representative for bransjen, enten om forholdet til lovgivning, kompromisser under forhandlingene eller om rimeligheten av løsningene. Fra forhandlingene kan det utledes argumenter som støtter opp under hvordan løsningene danner en balansert helhet. ${ }^{114}$ Denne typen argumenter er nært knyttet til argumentene om avtalens systematikk og vil derfor kunne få stor vekt ved tolkningen.

For det tredje er det forskjell mellom de ulike standardavtalene med hensyn til hvilken vekt det er naturlig å legge på argumenter hentet fra forhistorien. Sjøforsikringsplanen har blitt oppfattet å stå i en særstilling, jf. Rt-1998-1032, Lomita. ${ }^{115}$

Spørsmålet om tolkningsargumentenes vekt kommer først på spissen når argumentene veies mot hverandre. Dersom det finnes få holdepunkter for tolkningen, kan argumenter som ellers ville fått liten vekt bli avgjørende, se Rt-1997-626, Dale-genseren. I praksis synes Høyesterett helst å legge vekt på argumenter fra avtalens tilblivelseshistorie når de støtter andre argumenter i samme retning. I Rt-2014520, Repstad anlegg, viste historien bak NS 8406 pkt. 28 at formuleringen tok sikte på å avklare en

\footnotetext{
112 Jf. også Rt-1980-1037.

${ }^{113}$ Se HR-2016-1447-A avsnitt 47-57.

${ }^{114}$ Se Rt-2000-806 på s. 815, Mads Bryde Andersen, Grundlaggende aftaleret, 2013, s. 350.

115 Se Rt-1956-920, Rt-1956-937, Rt-1969-126 og Rt-1998, 1032, jf. Thor Falkanger, «Tolkning av sjørettslige

standardkontrakter - særlig om betydningen av forarbeider», Ånd og rett - Festskrift til Birger Stuevold Lassen, 1997, s. 289

flg. og Hans Jacob Bull, «Avtalte standardvilkår som privat lovgivning», i Lov, dom og bok: Festskrift til Sjur Brakhus, 1988, s. 99 på s. 110.
} 
uklarhet i den tidligere versjonen, og at bransjen var klar over denne uklarheten. Argumentene fra forhistorien støttet argumenter knyttet til avtalens språk og systematikk. ${ }^{116}$

Høyesterett viser oftere til litteratur om standardkontraktene hvor generelle tolkningsspørsmål er diskutert. ${ }^{117}$ Disse er gjerne skrevet av personer med stor erfaring på området, de er tilgjengelige for alle, og bruker rettskildene til å diskutere generelle tolkningsspørsmål. Høyesterett bruker imidlertid også disse argumentene først etter å ha sett på ordlyden og bakgrunnsrettten. ${ }^{118}$ Kan man hente argumenter fra bakgrunnsretten, vil slike argumenter etter mitt syn fremme hensynet til forutberegnelighet bedre enn argumenter fra avtalens tilblivelseshistorie. ${ }^{119}$ Alt i alt synes det ikke grunnlag for å legge særlig stor vekt på argumenter hentet fra standardkontraktens forarbeider.

\subsection{Reelle hensyn}

Reelle hensyn omfatter argumenter som knytter seg til resultatet av rettsanvendelsen i sammenheng. ${ }^{120}$ Det rommer både hensynet til hvilken regel som generelt gir en god løsning, og hva som gir en god løsning i det konkrete tilfellet. ${ }^{121}$ Reelle hensyn har betydning ved tolkning av standardavtaler, jf. Rt2010-960 avsnitt 44. ${ }^{122}$ Høyesterett tenker nok som utgangspunkt på reelle hensyn av generell karakter, som virkningsvurderinger og systembetraktninger. ${ }^{123}$ Spørsmålet er om det i det hele tatt er rom for konkrete rimelighetsvurderinger der partene har brukt en forhandlet standardkontrakt. Spørsmålet kommer bare på spissen der det som generelt oppfattes som en god løsning ikke oppfattes å gi en god løsning i det konkrete tilfellet. ${ }^{124}$

\footnotetext{
${ }^{116}$ Se Rt-2014-520, Repstad anlegg, avsnitt 30 flg. og HR-206-1447-A, Norsk Gjenvinning.

117 Jf. Rt-1981-445 på s. 450, Rt-1986-1386 på s. 1394, Rt-1998-656 på s. 664, Rt-1997-1086 på s. 1095 og Rt-1999-878. Det er ikke alltid at Høyesterett slutter seg til de generelle tolkningene, se Rt-2013-1476 avsnitt 52.

${ }^{118}$ Sml. dog Högsta Domstolens uttalelser i T 3671-17.

${ }^{119}$ Slik også Anders Ingvarson og Marcus Utterstrøm, «Högsta domstolens intåg i entreprenadrättens slutna rum», SvJT, 2015 s. 258, med henvisning til NJA 2012 s. 597, NJA 2013 s. 271, NJA 2014 s. 960.

${ }^{120}$ Det er en større diskusjon i teorien om innholdet i begrepet «reelle hensyn» som ikke skal løftes her, se Nils Nygard, Rettsgrunnlag og standpunkt, 2004, s. 30-31. Den Eckhoffske begrepsbruken fokuserer på resultatets godhet og rimelighet, se Torstein Eckhoff og Jan Helgesen, Rettskildelare, 2001 s. 357. Jens Edvin A. Skoghøy, «Rett, politikk og moral. Om bruk av politiske og etiske argumenter ved rettsanvendelse og juridisk forskning», TfR, 1994 s. 837, viser til at «reelle hensyn» omfatter både virkningsorienterte, innholdsmessige og systemorienterte vurderinger. Jeg er enig i Skoghøys argumentasjon, men for å gjøre fremstillingen mer effektiv, bruker jeg «god løsning» som felles stikkord.

121 Jf. Rt-1991-719 på s. 726.

${ }^{122}$ Sml. Högsta domstolen i NJA 2014 s. 960 og NJA 2015 s. 862, som viser til en overgripende rimelighetsvurdering. Etter norsk språkbruk vil det antyde en snevrere gruppe argumenter. Avgjørelsene gir imidlertid ikke grunnlag for å si at det er en realitetsforskjell mellom norsk og svensk rett på dette punkt, se særlig NJA 2015 s. 862.

123 Jf. Skoghøy, ibid. note 120. Se også Kåre Lilleholt, «Bruk av reelle omsyn i formueretten», Jussens Venner 2000 s. 49.

${ }^{124}$ Se Rt-2006-1076, der partene i en entreprisekontrakt hadde tatt inn begrepet «back-to-back», jf. pkt. 1.2 NS 3430.

Høyesterett tolket henvisningen slik at den hadde en begrenset rekkevidde, og unngikk dermed et uheldig resultat i det konkrete tilfellet.
} 
På grunn av det «subjektive underskuddet» ved tolkningen av standardkontrakter, jf. avsnitt 1.2, går tolkningen ofte ikke ut på å finne ut hvordan teksten gir uttrykk for hva partene mente. Tolkningen går heller ut på å bestemme hvem av partene det bør gå ut over at man ikke har hatt oversikt over alle konsekvenser av ordlyden i standarden. Med et utgangspunkt om at hver av partene bærer risikoen for egne forutsetninger, blir det vanskelig å legge stor vekt på at en regulering har individuelle uheldige virkninger dersom den generelt oppfattes som en god løsning. I Rt-2005-788, Oslofjordtunnelen, var spørsmålet om entreprenøren hadde krav på dekning av «merutgifter» som skyldtes fordyrelser som var byggherrens risiko, selv om de totale utgiftene for entreprenøren ikke ble større enn han hadde beregnet ved anbudet. Høyesterett kom til at etter avtalens system hadde entreprenøren risikoen for fremdriftsplanen, og da ville det ikke være rimelig at innsparinger som entreprenøren gjorde skulle «spises opp» av fordyrelser som var byggherrens risiko (avsnitt 45-47). Høyesterett valgte dermed en regel som var rettsteknisk mer komplisert, fordi merutgiftene måtte beregnes ut fra prosjektet som det ble og ikke anbudet, ut fra hensynet til hva som generelt ville gi et godt resultat.

På samme måte kan det at kontrakten etablerer rigide systemer for å unngå tvister og usikkerhet, som reglene i NF 15 og NTK 15 art. 16.1 om preklusjon av innsigelser om arbeidets omfang, føre til at små forsømmelser i å etterleve kontraktens formelle regime får store konsekvenser for parten i det enkelte tilfellet. Hensynet til å oppnå generelt gode løsninger, for endringsreglene, ved at arbeidet kan fortsette selv om partene er uenige om tolkningen av kontrakten, vil imidlertid ofte oppveie den urimelighet som oppstår ved brudd på frist- eller preklusjonsregler. ${ }^{125}$

Standardkontraktene er utarbeidet for å brukes i mange avtaleforhold. Spørsmålet er om det kan tilsi at terskelen for å legge vekt på individuelle rimelighetshensyn heves. Dersom de konkrete rimelighetshensynene slår likt ut i mange avtaleforhold, typisk for ensidige massevilkår som forsikringsvilkår, vil innskrenkende tolkning (eller revisjon) på grunnlag av individuelle rimelighetshensyn kunne skape usikkerhet om innholdet i tilsvarende avtaleforhold. ${ }^{126}$ Det samme gjelder forhandlede standarder som brukes mye i en bransje, eller der myndighetene skaper incentiver til å bruke dem, som anskaffelsesforskriftens $§ 19-11$ og myndighetenes praksis for å stille krav om at all virksomhet på grunnlag av utvinningstillatelsene på norsk sokkel skal være underlagt norsk rett og bygge på norsk kontraktstradisjon. ${ }^{127}$ I disse tilfellene veier hensynet til tredjeparts forutsigbarhet spesielt tungt.

Når hensynet til det som generelt er et godt resultat prioriteres foran eventuelle uheldige utslag av reguleringen i det konkrete tilfellet, er det en situasjon som er spesiell for standardkontrakter og

\footnotetext{
${ }^{125}$ Se Knut Kaasen, «Formalisme i komplekse tilvirkningskontrakter», Tidsskrift for Forretningsjus, 2009 s. 47, på s. 55.

126 Jf. Rt-2005-1112 og Rt-2004-1545, om lemping av forsikringsvilkår.

${ }^{127}$ Se Knut Kaasen, «Petroleumsretten», i Kåre Lilleholt (red.), Knophs Oversikt over Norges rett, 2014 s. 359. Før 2015 hadde Statoil ASA og Hydro Produksjon AS forpliktet seg til å bruke NF/NTK i sine kontraktsforhold.
} 
masseavtaler i forhold til individuelle kontrakter. Dette er jo konsekvensen av at avtalene er utformet for å brukes mange ganger, og som bringer hensynet til tredjeparts forutberegnelighet inn i tolkningen.

\section{Tolkningsregler ${ }^{128}$}

\subsection{Minimumsregelen}

Den såkalte minimumsregelen har vært formulert som «en presumsjon for den minst byrdefulle forpliktelse». ${ }^{129}$ Regelen er kjent fra fransk rett, hvor den er lovfestet i Code Civil art. 1190 (2016). Regelens begrunnelse er en generell antagelse om at parten ikke har ønsket å binde seg til mer enn det som fremgår uttrykkelig av avtalevilkårene. Som tolkningsregel ligger minimumsregelen et sted mellom bevisspørsmål og de risikospørsmål som håndteres i uklarhetsregelen. Regelen har ikke satt særlig tydelige spor i norsk rettspraksis. ${ }^{130}$ Teorien påpeker betenkelighetene med å anvende prinsippet i gjensidig bebyrdende kontrakter, der en tolkning til fordel for en part automatisk fører til en ulempe for kontraktsmotparten. ${ }^{131}$ Ved tolkning av forhandlede standardkontrakter kommer i tillegg hensynet til standardens karakter av kompromiss mellom bransjeaktørene. Å bruke minimumsregelen ved tolkningen av ett vilkår, kan føre til ubalanse i sammenheng med andre vilkår. På den annen side er tolkningen av standardkontrakter preget av det «subjektive underskuddet», altså at det er få holdepunkter for å fastslå hvordan partene faktisk oppfattet de enkelte vilkår i teksten. Da kan regler som minimumsregelen muligens inngå i den objektive tolkningen av ordlyden, jf. pkt. 3, om den trekkes inn i vurderingen av hvordan en normalt aktsom tredjepart ville oppfatte vilkåret.

Dersom det er tvil om en part har ment å binde seg til en forpliktelse med et så byrdefullt innhold, synes Høyesterett heller å ha løst det ved å stille strenge krav til at vilkåret er vedtatt av parten. I Rt-2004-675, Agurkpinne, avsnitt 72-73, hadde selger i salgsbetingelsene som ble oversendt kjøper med fraktbrevet, tatt inn en ansvarsfraskrivelse som innebar en betydelig overføring av risiko fra selger til kjøper. Høyesterett viste til at vilkåret ikke hadde vært omtalt mellom partene, og fant at vilkåret ikke kunne anses vedtatt. HR-2017-971-A, Presentwater, gjaldt spørsmålet om det var inngått avtale om salgsprovisjon. Høyesterett synes å stille et strengere aktsomhetskrav til løftemottaker for å kunne bygge på en berettiget forventning om at motparten har bundet seg til et vilkår med et tyngende innhold, se avsnitt 41-42, jf. 45.

På enkelte områder kan en minimumsregel være berettiget. Bernitz nevner overdragelse av immaterialrettigheter og konkurranseforbud. ${ }^{132}$ På disse områdene gjelder imidlertid spesialregler som virker i samme retning, som spesialitetsgrunnsetningen i åvl. § 39 a og avtalelovens § 38 .

Spesialreglene har en særlig begrunnelse, henholdsvis hensynet til opphavsmannens stilling som den

\footnotetext{
${ }^{128}$ Se note 29. Jeg bruker «tolkningsregel» om typiske hensyn som formuleres som konkrete retningslinjer for tolkningen.

${ }^{129}$ Kai Krüger, Kontraktsrett, 1989, s. 533, jf. Rt-1930-799 og Erlend Haaskjold, Kontraktsforpliktelser, 2013, s. 323.

130 Jf. Lilleholt 2017, s. 113, Erik Røsæg, Garantier eller fattigmanns trøst? Stфtteerklaringer av typen «comfort letters», 1992, s. 522-523, heller ikke i svensk rett, jf. Bernitz 2013, s. 101 og Mattias Hedwall, Tolkning av kommersiella avtal, 2004 s. 78.

${ }^{131}$ Se bl.a. Kai Krüger, Kontraktsrett, 1989, s. 534 og Marcus Radetzki, Tolkning av försäkringsvillkor, 2014 s. 33.

${ }^{132}$ Bernitz 2013, s. 101.
} 
presumptivt svakere part og hans personlige forhold til verket, og vern for arbeidstakere, og disse hensynene må slå igjennom også i forhold til forhandlede standardkontrakter. Det blir i så fall lite rom for en generell minimumsregel ved siden av i disse tilfellene.

\subsection{Uklarhetsregelen}

I norsk avtalerett har $u$ klarhetsregelen stor praktisk betydning som tolkningsregel. ${ }^{133}$ Forfatterregelen går ut på at avtalen ved tvil om innholdet skal tolkes mot den part som har utformet avtalen. Ved tolkning av forhandlede standardkontrakter er det imidlertid ingen av partene som normalt har forfattet teksten, og regelens begrunnelse treffer derfor ikke så godt. ${ }^{134}$ Her skiller de forhandlede standardkontraktene seg fra ensidig utarbeidede standardvilkår. Når den ene parten har brukt tid og ressurser på å utarbeide standardvilkår, kan det føre til at det blir vanskeligere å forhandle enkeltvis om kontraktsvilkårenes innhold. Da realiseres hensynene bak uklarhetsregelen. ${ }^{135}$ Det formuleres derfor av og til som et generelt utgangspunkt at ensidig utarbeidede standardvilkår tolkes restriktivt mot den som har utarbeidet vilkårene, også i kommersielle forhold. ${ }^{136}$

Uklarhetsregelens nedslagsfelt er der det er uklart hvilken regulering som følger av kontraktens bestemmelse. Uklarhet med hensyn til kontraktens dekningsomfang - altså at det har oppstått en situasjon som partene ikke tenkte på ved kontraktsinngåelsen, og det er tvil om situasjonen faller innenfor en i og for seg klar regel i kontrakten, faller nok utenfor uklarhetsregelens kjerneområde, og blir et spørsmål om partenes forutsetninger. ${ }^{137}$

Uklarhetsregelens begrunnelse, nemlig at tolkningstvil bør gå utover den part som etter forholdene burde ha uttrykt seg klarere, treffer der det er gjort individuelle avvik fra standardkontrakten, jf. Rt2009-160, Stryn Energi. Partene hadde avtalt at varslingsfristen i NS 3431 pkt. 22.5 bare skulle være 24 timer. Høyesterett viste til at konsekvensene av fristoversittelse var store, i det tilfellet bortfall av et krav på over ni millioner kroner. En uklarhet om hvilken varslingsfrist som skulle gjelde for det aktuelle kravet, måtte gå ut over byggherren som hadde formulert kontrakten (avsnitt 45).

Kontrakter inngått etter anbudskonkurranse bør behandles særskilt i relasjon til uklarhetsregelen. Etter anskaffelsesforskriften $\S 14-1(5)$ har oppdragsgiver risikoen for uklarheter i konkurransegrunnlaget. ${ }^{138}$ Anskaffelsesforskriften $\S 19-11(1)$ forutsetter at oppdragsgiveren bruker de forhandlede

\footnotetext{
${ }^{133}$ Se Rt-2011-1553 avsnitt 61, og Geir Woxholth, Avtalerett, 2017, s. 440.

${ }^{134}$ Slik Erlend Haaskjold, Kontraktsforpliktelser, 2013, s. 416 og Lennart Lynge Andersen og Palle Bo Madsen, Aftaler og mellemmand, 2017 s. 409.

${ }^{135}$ Se Rt-1992-1105, NOU 1976:61 s. 60, Geir Woxholth, Avtalerett, 2017, s. 414 og Bernitz 2013, s. 96. For forbrukerforhold følger dette av avtaleloven $\S 37$ første ledd nr. 3.

${ }^{136}$ På forsikringsrettens område fører dette til at uklarhet i forsikringsvilkårene regelmessig blir tolket mot selskapet, se Rt1980-1037, Rt-1997-1807, Hans Jacob Bull, Forsikringsrett, 2008 s. 147. Det gjelder ikke ved tolkning av Sjøforsikringsplanen, fordi den er et forhandlet dokument, jf. Hans Jacob Bull ibid. s. 151.

137 Jf. Ramberg og Ramberg 2016 s. 186, med henvisning til NJA 2010 s. 416.

${ }^{138}$ FOR-2016-08-12-974, jf. Rt-2007-1489, avsnitt 62 og Rt-2012-1279, avsnitt 58, gjentatt i Rt-2014-866, avsnitt 41.
} 
standardkontraktene, som hovedregel NS 8405, NS 8406 og NS 8407. Ved offentlige anbud inngås kontrakten på grunnlag av konkurransegrunnlaget og det aksepterte anbudet, uten forhandling om kontraktens vilkår. Det betyr at hensynet til andre tilbydere har betydelig vekt ved tolkningen av den kontrakten som inngås med den valgte anbyderen. ${ }^{139}$ Domstolene har vært lite villige til å tolke kontrakten på en måte som reduserer virkningene av eventuelle regelbrudd, og anbyderne pålegges ingen unders $ø$ kelses- eller varslingsplikt for uklarheter i konkurransegrunnlaget. ${ }^{140}$

Utenfor disse tilfellene blir spørsmålet om uklarhetsregelen i andre nyanser kan få betydning for tolkningen, fordi det er en særlig begrunnelse for å legge risikoen for tolkningstvil på en av partene. Utenfor forfatterregelen er nok «uklarhetsregelen» mer uttrykk for en typifisering av hensyn enn en egentlig tolkningsregel. I én utforming av uklarhetsregelen legges tolkningsrisikoen på den av partene som introduserer teksten. ${ }^{141}$ Så lenge de forhandlede standardkontraktene anvendes innenfor sitt tiltenkte område, kan en nok forvente at begge parter har kunnskap om standarden, slik at det er vanskelig å legge tolkningsrisiko på den av partene som introduserer vilkårene. Dersom kontraktene anvendes utenfor sitt tiltenkte område, kan det imidlertid være åpning for å plassere tolkningsrisiko hos den part som introduserer vilkårene.

To andre varianter av uklarhetsregelen går ut på at avtalen tolkes mot den som hadde de beste forutsetninger for å unngå uklarheter eller mot den av partene som er særlig kyndig eller ressurssterk. I disse tilfellene søker «regelen» å korrigere skjevheter som følge av ulikhet i forhandlingsstyrke og forutsetninger hos partene. For de forhandlede standardkontraktene, vil slik ulikhet presumptivt være utlignet når kontrakten er fremforhandlet mellom bransjeorganisasjoner. ${ }^{142}$

Det finnes imidlertid enkelte situasjoner der de store standardkontraktene brukes i forhold der den ene parten er en fysisk person, og der personen «profesjonaliseres» gjennom sin rettslige rolle, som entreprisekontrakter om oppføring av bygg for private personer. Byggherren er «profesjonalisert» i sin rettslige rolle, men har ikke samme forutsetninger som et entreprenørselskap til å ta inn over seg konsekvensene av alle vilkårene i NS 8406. ${ }^{143}$ En tilsvarende situasjon kan tenkes der FIDIC kontraktene brukes når en enkeltstående ingeniør tar oppdrag for et større selskap. Så lenge kontrakten brukes innenfor sitt tenkte anvendelsesområde, gjelder jo forutsetningen om at vilkårene er balansert gjennom bransjeorganisasjonens forhandlinger. Ved tolkningsspørsmål som gjelder vilkårenes

\footnotetext{
${ }^{139}$ Se Rt-2003-1531.

140 Jf. Rt-2001-1288 og Rt-2005-1481. Se Viggo Hagstrøm og Herman Bruserud, Entrepriserett, 2014 s. 165 flg. og Kai Krüger, «Tolkning av kontrakter som er tildelt ved anbudskonkurranse», i Lasse Simonsen og Jan Einar Barbo (red.) På rett grunn: Festskrift til Norsk forening for bygge- og entrepriserett, 2010 s. 111, på s. 114 jf. s. 127.

${ }^{141}$ Jf. PECL Art. 5:103 og UNIDROIT Principles Art. 4.6. Disse er nok myntet på ensidige standardvilkår.

${ }^{142}$ Se NOU 1976:61 s. 68.

${ }^{143}$ Se LB-1997-3165, omtalt under pkt. 4.2.3.
} 
anvendelse, rekkevidden av individuelle vilkår i forhold til standardvilkårene eller lignende, kan etter mitt syn en risikoavveining med utgangspunkt i disse sidene av uklarhetsregelen være aktuelt.

Etter mitt syn vil det kun unntaksvis være aktuelt å anvende uklarhetsregelen på tolkningen av vilkårene i en forhandlet standardkontrakt. Det er klart at norsk avtalerett legger en god del vekt på generelle hensyn til lojalitet og god tro, og at dersom en part har hatt en oppfordring til å avklare uklarheter, vil det kunne få betydning for avtalens innhold. Ved tolkning av forhandlede standardkontrakter, har nok disse hensynene hatt liten synlig betydning når det gjelder avklaring av uklarheter i ordlyden. Der det foreligger skyld, har det heller blitt håndtert under god tro-regelen, og der det er en markant ubalanse i avtaleinngåelsessituasjonen eller med hensyn til vilkårenes innhold, har det heller blitt stilt høyere krav til vedtagelse av vilkårene.

\section{Grensen mot avtalerevisjon - avtalelovens § 36}

Domstolene har vært svært tilbakeholdne med å anvende revisjonsregelen i avtl. § 36; i kommersielle avtaleforhold er det kun den «kvalifiserte urimelighet» som kan rammes. ${ }^{144}$ Når partene har brukt en forhandlet standardkontrakt, krysses hensynet til å sette grenser for urimelighet i det konkrete forholdet av hensynet til at standardkontrakten skal fungere som et kompromiss for bransjeinteresser; interesser som kanskje ikke bæres fullt ut av de aktuelle kontraktspartene. Spørsmålet er om dette fører til at terskelen for lemping blir enda høyere, slik at det i praksis egentlig ikke blir aktuelt å lempe avtalevilkår i forhandlede standardkontrakter. ${ }^{145}$

For det første er det svært vanskelig å anvende avtl. § 36 på risiko som forelå på tidspunktet for avtaleinngåelsen, bare fordi risikoen materialiserer seg i ettertid. ${ }^{146}$ Hver av partene må $\mathrm{i}$ utgangspunktet sørge for at kontrakten regulerer den risiko som deres kontraktsytelse påvirkes av. Det gjelder alle kommersielle avtaler, men muligheten for at det skal være en diskrepans mellom kontraktens ordlyd og den oppståtte risiko, er kanskje større når partene ikke selv forhandler frem vilkårene.

Høyesterett kan synes å ha vært noe mer villig til å vurdere lemping av avtaleforpliktelsene under læren om bristende forutsetninger, altså der et faktum som virket motiverende for hvilke kontraktsbetingelser som ble godtatt ved avtaleinngåelsen, har endret seg etterpå, enn etter en generell

\footnotetext{
144 Jf. Rt-2012-1537 avsnitt 46, Rt-2003-1132 avsnitt 46 og Rt-2000-806.

${ }^{145}$ I denne retning Kai Krüger, «Tolkning av kontrakter som er tildelt ved anbudskonkurranse», i Jan Einar Barbo og Lasse Simonsen (red.), På rett grunn, Festskrift til Norsk Forening for Bygge- og Entrepriserett, 2010 s. 111 på s. 120-121. 146 Jf. NOU 1979:32 s. 48, Rt-2010-1345, Oslo Vei, Rt-1995-245, Elcon Finans. I utgangspunktet gjelder dette også dersom følgene av at risikoen materialiserer seg er større enn partene hadde tenkt seg, se Rt-1987-1486 (som riktignok ikke nevner $\S$ 36), og Jan Einar Barbo, Kontraktsomlegging i entrepriseforhold, 1997 s. 320-321. Samme på generelt grunnlag, Lennart Lynge Andersen, Aftalelovens $§ 36$ - fra kontraktsfrihed til urimelighetskontroll, 2017 s. 251-253.
} 
urimelighetsvurdering. ${ }^{147}$ Men, terskelen for lemping er svært høy uansett. Jeg har ikke funnet noen eksempler i norsk rettspraksis på at en forhandlet standardavtale har blitt lempet, verken etter avtl. § 36 eller etter læren om bristende forutsetninger. ${ }^{148}$

Rt-2010-1345, Oslo Vei, gjaldt en avtale om vegvedlikehold som var blitt vesentlig dyrere enn forutsatt på grunn av økt saltforbruk om vinteren. Høyesterett (avsnitt 65) viste til at risikoen for hvilke saltmengder som var nødvendige for å oppfylle kontraktens krav til vegstandard bevisst var plassert hos entreprenøren. Læren om bristende forutsetninger kunne ikke gi grunnlag for å omfordele den risikoen, selv om entreprenøren hadde påtatt seg risikoen basert på opplysninger om historisk saltforbruk fra byggherren, og det senere viste seg at det var feil i disse opplysningene. I avsnitt 66 jf. 68 fremgår at revisjon etter avtaleloven $\S 36$ er mulig basert på en helhetlig rimelighetsvurdering, men at det skal svært mye til. ${ }^{149}$

For det andre kan det at standarden anvendes i stor utstrekning i bransjen, medføre at terskelen for urimelighet korrelerer med standardens løsninger. ${ }^{150}$ Når avtalen er forhandlet mellom representanter for bransjeinteresser, kan det føre til en presumsjon for at avtalens løsninger er rimelige og balanserte fordi eventuell ulikhet i styrkeforhold i forhandlingssituasjonen er utjevnet. ${ }^{151}$ Dessuten kan det at bransjeaktørene kjenner til standarden, bidra til å sette en ramme for aktørenes forventninger om hva som er en rimelig avveining av plikter og rettigheter mellom aktørene.

Det kan være lettere å lempe ensidige standardvilkår etter avtalelovens § 36, vel å merke for den svakere part i avtaleforholdet, på grunn av ulikheten i styrkeforholdet mellom partene. ${ }^{152}$ Dette hensynet krysses imidlertid av hensynet til generell forutsigbarhet dersom vilkårene brukes i masseavtaler. Høyesterett har avvist lemping av forsikringsvilkår fordi det ville føre til usikkerhet om hva som gjelder i andre avtaleforhold, se Rt-2005-1112 og Rt-2004-1545. Det avgjørende må bli en vurdering av hvor urimelige vilkårene fremstår, om avtalen er fremkommet på en måte som oppveier ulikhet $\mathrm{i}$ forhandlingsstyrke, og hvilke vilkår det eventuelt er snakk om å lempe.

For det tredje kan de store standardkontraktene spille en slik rolle i rettsutviklingen at avtl. § 36 ikke egner seg som et verktøy for samfunnsstyring. Utviklingen av ansvarsregulering etter knock-forknock-prinsipper, kan illustrere poenget. Mange av de store standardkontraktene har vidtgående ansvarsfraskrivelser kombinert med en plikt til, eller en praksis for, å tegne forsikringer som dekker egne tap, uavhengig av årsaken til skaden. ${ }^{153}$ Da denne typen ansvarsregulering ble tatt i bruk, stilte

\footnotetext{
${ }^{147}$ Se Rt-199-922, Rt-2003-1132 avsnitt 46, Rt-2010-1345 avsnitt 65-68, og Rt-2014-520.

${ }^{148}$ Danske domstoler har vært mer tilbøyelige til å anvende $§ 36$ i kommersielle forhold, se diskusjon og oppsummering av praksis hos Lennart Lynge Andersen, Aftalelovens § 36, 2018 s. $341 \mathrm{flg}$.

149 Jf. også LB-2011-135964. Grensen mellom avtaleloven § 36 og forutsetningslæren er ikke helt klar, se Rt-1999-922, og Jan Einar Barbo, Kontraktsomlegging i entrepriseforhold, 1997 s. 319 flg., med henvisning til Kirsti Strøm Bull, Avtaler mellom ektefeller, 1993 s. 279.

${ }^{150}$ Se LB-2008-61987 og RG-1998-1330.

${ }^{151}$ Se Rt-2004-1545 avsnitt (52) om tolkning av forsikringsavtale, Erlend Haaskjold, Kontraktsforpliktelser, 2013 s. 427, og Petra Sund-Norrgård, Tolkningen av franchiseavtal, 2014 s. 106.

${ }^{152}$ Ensidige standardvilkår anvendt i forbrukerforhold er gjenstand for urimelighetskontroll under markedsføringslovens $\S$

22, jf. EUs direktiv (93/13) om urimelige vilkår i forbrukerkontrakter.

${ }^{153}$ Se NS 8405 pkt. 36.5 og NTK/NF 15 pkt. 30 og 31.
} 
teorien spørsmål ved om partene etter norsk rett hadde adgang til å fraskrive seg ansvar ved grovere skyldformer. ${ }^{154}$ Da spørsmålet kom opp for Høyesterett i Rt-1994-626, avviste Høyesterett å lempe en slik ansvarsregulering etter avtl. § 36, nettopp fordi det var tale om forhandlede standardvilkår (NSAB). ${ }^{155} \mathrm{I}$ dag antas at slike ansvarsfraskrivelser i de store standardene er gyldige. ${ }^{156}$ Rettsutviklingen omkring de store standardene skjer når bransjen blir kjent med og knytter forventninger til kontraktene, så danner det seg en praksis og etter hvert en rettsregel. Da blir det vanskelig å si at reguleringen er kvalifisert urimelig. Avtaleloven $\S 36$ og forutsetningslæren retter seg mot virkningene av kontrakten mellom partene, og tar ikke sikte på å korrigere eventuelle samfunnsmessige virkninger som forurensningsansvar og erstatningsansvar for tredjemannsskader. ${ }^{157}$

Samfunnskontroll med forhandlede standardvilkår, skjer antagelig best gjennom spesiallovgivning som setter grenser for kontraktsfriheten for å ivareta samfunnsmessige hensyn. For eksempel under forbudet mot misbruk av en dominerende markedsstilling i konkurranseloven $\S 11$, kan det at foretaket anvender de samme vilkårene i mange avtaleforhold, nettopp forsterke vilkårenes konkurransevridende effekt, og dermed gjøre vilkårene mer utsatt for kontroll. Slike massevirkninger virker forstyrrende i den avtalerettslige urimelighetsrevisjonen, der revisjon vil føre til en ny «urimelighet» fordi vilkårene blir ulike i ellers like forhold, eller der massevirkningen påvirker urimelighetsstandarden. ${ }^{158}$

Der standardvilkår, kanskje oftest ensidige vilkår, virker urimelig tyngende for den ene part, er det eksempler på at Høyesterett heller stiller strenge krav til vedtagelsen av vilkårene enn å lempe vilkårene etter avtl. § 36. Også i kommersielle forhold, kan det være lettere å si at dersom parten først har akseptert standardvilkårene som inkluderer et særlig tyngende vilkår, må han leve med at den risikoen også materialiserer seg, men at det i så fall kreves sikkerhet for at han faktisk har vedtatt vilkåret, jf. Rt-2004-675, agurkpinne, avsnitt 73 og Rt-2017-971-A, Presentwater, se pkt. 5.1.

\footnotetext{
${ }^{154}$ Grovt og upresist, men tilstrekkelig for temaet her. Se Viggo Hagstrøm, «Om grensene for ansvarsfraskrivelse, særlig i næringsforhold», TfR 1996 s. 421 og Mads Bryde Andersen, Grundlaggende aftaleret, 2013 s. 437 flg. sml. UNIDROIT Art. 7.1.6.

155 Tilsvarende har Dansk Højesteret avvist å lempe spedisjonsvilkårene (NSAB) etter § 36, U 2006.632.

${ }^{156}$ Se Knut Kaasen, Petroleumskontrakter med kommentarer til NF 05 og NTK 05, 2006, s. 749-750 med henvisninger.

${ }^{157}$ Dette er en større diskusjon i teorien, som det ikke er rom for å løfte frem i full bredde her. Lennart Lynge Andersen og Palle Bo Madsen, Aftaler og mellemmand, 2017, s. 356-357 er kritiske til at domstolene er så tilbakeholdende med å bruke $\S$ 36. Motsatt, Knut Kaasen, Petroleumskontrakter med kommentarer til NF 05 og NTK 05, 2006, s. 750-757.

158 Tysk rett har egne lovbestemmelser om kontroll med urimelige standardvilkår, BGB § 305-§ 310. Reglene har sin bakgrunn i ordoliberalistisk markedsøkonomisk teori (Freiburg-skolen), som er det første økonomisk teoretiske grunnlaget for konkurransebegrensningsreglene i EU, i dag TFEU art. 101 og 102, og det brukes som argument for at innholdskontroll med disse avtalene heller bør skje etter konkurransereglene, se diskusjon hos Matthias Lehmann og Johannes Ungerer, «Save the «Mittelstand»: How German Courts Protect Small and Medium-Sized Enterprises from Unfair Terms», European Review of Private Law, 2017 s. 313, på s. 326.
} 


\section{Resultater: Egne tolkningsregler for forhandlede standardavtaler?}

\subsection{Kan tolkningen best karakteriseres som «lovtolkning»?}

I teorien har det blitt tatt til orde for at tolkning av forhandlede standardavtaler, har større likhet med tolkningen av lover enn avtaletolkning. ${ }^{159} \mathrm{Jeg}$ mener en bør være varsom med en slik karakteristikk. Synspunktet kan for det første ikke gjelde den partsspesifikke delen av tolkningen. Partenes felles mening binder alltid domstolene på grunn av privatautonomien. Det finnes ikke støtte i nordisk rettspraksis for å se bort fra individuelle omstendigheter i tolkningen. For det andre, forutsetter en «lovtolkningsmetode» at den faktiske rammen for den objektive tolkningen er standardisert. I praksis kan det vanskelig tenkes at to avtaleforhold er så like. Endelig kan det å karakterisere tolkningen som «lovtolkningslignende» implisere at standardens «forarbeider» rykker oppover i tolkningsargumentenes vekthierarki, slik at forhandlernes vilje blir et selvstendig tolkningsargument. Noen slik legitimering av forhistorien har jeg ikke funnet noe grunnlag for.

\subsection{En tolkningsregel om uniform tolkning?}

En kunne tenke seg en egen regel om uniform tolkning for forhandlede standardkontrakter, som måtte gå ut på at avtalen så langt som mulig bør tolkes likt hver gang. ${ }^{160}$ En slik tolkningsregel måtte forutsette at argumenter fra tidligere tolkninger av standarden legitimeres på selvstendig grunnlag, altså i kraft av å være tidligere tolkningsuttalelser. Med mindre standardkontrakten har blitt en del av bakgrunnsretten, se pkt. 4.2.3, synes det vanskelig. For det første får en problemer fordi det er faktiske ulikheter i alle avtaleforhold. For det andre, er tidligere tolkningsuttalelser statiske og fanger ikke opp utvikling i bakgrunnsretten. Indirekte kan likevel tidligere tolkningsavgjørelser ha stor betydning, fordi avgjørelser som avklarer tolkningsspørsmål av mer generell karakter, absorberes i bransjens oppfatning av vilkårene, og dermed bidrar til rettsutviklingen omkring standardavtalene.

\subsection{Slutning}

Etter dette, er det kanskje særlig to ting som gir innhold til setningen om at den objektive tolkningen har særlig tyngde ved tolkning av forhandlede standardkontrakter.

\footnotetext{
${ }^{159}$ Om de sjørettslige standardkontraktene, Hans Jacob Bull, «Avtalte standardvilkår som privat lovgivning», i Lov, dom og bok: Festskrift til Sjur Brakhus, 1988 s. 99 flg. på s. 108 og Thor Falkanger, «Tolkning av sjørettslige standardkontrakter særlig om betydningen av forarbeider», Ånd og rett-Festskrift til Birger Stuevold Lassen, 1997, s. 289 flg. på s. 294, jf. Rt1998-1032, Lomita, på s. 1038: «Både når det gjelder den systematiske oppbygning og utformningen av de enkelte regler, ligner Planen mer på en lov enn på en vanlig standardkontrakt. Også dette må tas i betraktning ved tolkningen. Prinsippene for tolkning av lover vil som regel passe bedre enn de vanlige regler om tolkning av avtaler». På generelt grunnlag Erlend Haaskjold, Kontraktsforpliktelser, 2013 s. 415. Se diskusjonen hos Jan Hellner, «Tolkning av standardavtal», JV, 1994 s. 266. Mer moderate synspunkter hos Mads Bryde Andersen, Grundlaggende aftaleret, 2013 s. 344: en «kollektivisert» avtalerett, og Jens Schovsbo, Immaterialretsaftaler, 2001 s. 33: en «(...) objektiveret vurdering af aftalens resultat set i lyset af normalløsningen.»

${ }^{160}$ Andreas Meidell, «Standardvilkår som uniforme regler for internasjonale kontrakter: En introduksjon», Jussens Venner 1999 s. 399, undersøker muligheten for en slik regel i internasjonal voldgiftspraksis, men finner liten støtte for det.
} 
I den partsspesifikke tolkningen har det «subjektive underskuddet»som konsekvens at det ofte er en bevisulikhet mellom standardkontraktens løsning og et eventuelt avvikende individuelt avtalevilkår. Bevisene for det individuelle alternativet kan være fragmentariske og uklare, mens ordlydens tolkningsalternativ er bevist per se. Etter mitt syn er det ikke grunnlag for å stille høyere krav til bevisene for det individuelle tolkningsalternativet. Det faktiske grunnlaget for tolkningen må fastlegges etter vanlige bevisregler. Når den felles partsoppfatning utledes ved tolkning, som et spørsmål om hvilken berettigede forventning en part kunne ha på grunnlag av motpartens utspill, vil imidlertid kontraktens ordlyd fungere som et lodd og trekke resultatet mot ordlydens løsning. Ordlyden er, særlig når det gjelder de forhandlede standardkontraktene, uttrykk for en «normalforventning», som blir retningsgivende for partenes berettigede forventninger, særlig når ordlyden er «frikoblet» fra de konkrete partene. I tillegg kan ordlyden få ytterligere vekt i tolkningen, dersom standarden har blitt uttrykk for bakgrunnsrett eller standarden anses som bransjens mål på en god løsning. Resultatet er et krav om «sterke grunner» for et tolkningsresultat som fraviker ordlyden.

Den objektive delen av tolkningen kjennetegnes ved et «overskudd» av objektive tolkningsargumenter - tolkningen har en «objektiv slagside». Objektive tolkningsargumenter som fremmer forutsigbarhet virker sammen med bransjens opparbeidelse av erfaring med kontraktene, og fører til at tolkningen nok blir mer generell og abstrahert enn tolkning av individuelt forhandlede kontrakter. Samtidig gjør andre tolkningsmekanismer, som uklarhetsregelen, og urimelighetssensur gjennom avtalelovens $\S 36$, mindre inngrep i tolkningen og i avtalens liv enn ved individuelle avtaler. På grunn av disse trekkene er det naturlig at tolkningsresultatet nokså ofte blir likt, selv om avtalene er brukt i ulike konkrete kontraktsrelasjoner. Etter mitt syn er det ikke nødvendig med egne tolkningsregler eller karakteristikker av tolkningsprosessen for forhandlede standardkontrakter - selv om det at objektiv tolkning har særlig gjennomslagskraft, kan være et godt navn på resultatet. 